\title{
A Revogação da Isenção da Cofins para as Sociedades Civis de Profissionais Liberais
}

$\overline{\text { Maurício Nedeff Langaro }}$

\section{INTRODUÇÃO}

O tema a ser tratado, revogação da isenção da COFINS para as sociedades civis de profissionais liberais, não é de todo simples, pois diz respeito, principalmente, a existência ou não de hierarQuia constitucional entre leis ordinárias e leis complementares. Isso porque a isenção foi instituída por lei complementar e a revogação se deu por lei ordinária.

A título introdutório, discorrer-se-á sobre o processo legislativo brașileiro, Que engloba a lei e seus aspectos gerais, como a previsão constitucional do processo legislativo. as espécies normativas existentes no ordenamento jurídico, a lei em sentido lato e restrito.

Mas, o aspecto da lei em si não é o suficiente, e como o problema da revogação da isençã́o da COFINS para as sociedades civis engloba, a princípio, a Questão da hierarquia entre leis ordinárias e complementares, será preciso analisar os requisitos formais para a elaboração de cada uma dessas duas espécies normativas, adentrando-se no aspecto da reserva constitucional ao campo material de incidência, ou methor, sobre quais assuntos a lei ordinária pode verdadeiramente tratar sem incorrer em inconstitucionalidade, o mesmo se aplicando a lei complementar.

Passada esta fase, chega-se ao campo específico da necessidade de lei complementar em matéria tributária, um aspecto nitidamente constitucional, e que requer, acima de tudo, leitura atenta da Constituição Federal de 1988.

Logo em seguida, após se analisar os atributos das leis ordinárias e leis complementares, e leis complementares em matéria tributária, procura-se estabelecer a existência ou não de hierarquia entre leis ordinárias e leis complementares, principalmente frente à Constituição Federal de 1988, o Que já se adianta não é problema só de direito tributário, apesar de, neste campo, se situarem as maiores controvérsias. Tocante à hierarquia entre leis ordinárias e leis complementares, se dará a posição doutrinária e, acima de tudo, do Supremo Tribunal Federal, órgão máximo em matéria constitucional. 
Finalmente, trata-se da COFINS, uma contribuição para a seguridade social, e mais especificamente à sua instituição por lei complementar, a Lei Complementar número 70/91, a Qual isentou as sociedades civis de prestação de serviços profissionais relativos ao exercício de profissão legalmente regulamentada - as ditas Sociedades Civis (de advogados, médicos, contadores etc.) - do seu recolhimento. Sem esquecer, então, Que, no ano de 1996, a Lei Ordinária número 9.430, em seu artigo 56, revogou expressamente dita isenção.

Importante, por isso, destacar que a isenção foi instituída por Lei Complementar, por outro lado, a revogação deu-se por Lei Ordinária.

Em relação a Cofins, ainda, se discorrerá sobre sua finalidade, competência para sua instituição, ente arrecadatório etc.

Pertinente, portanto, enfatizar se havia ou não necessidade de lei complementar para a instituição da COFINS, e a réspectiva posição doutrinária e jurisprudencial. principalmente do Supremo Tribunal Federal. Denegrido este ponto, poder-se-á definir se a revogação da isenção da Cofins para as sociedades civis de profissionais liberais poderia ou não ter ocorrido por lei ordinária, citando as posições da doutrina, e. principalmente, do Superior Tribunal de lustiça e do Supremo Tribunal Federal.

A relevância atual do tema está justamente em Que a insegurança não pode prevalecer, ou seja, uma posição definitiva sobre a matéria - revogação da isenção da COFINS para as sociedades civis de profissionais liberais - precisa ser tomada, independentemente se favorável ao fisco ou ao contribuinte.

\section{PROCESSO LEGISLATIVO, LEIS ORDINÁRIAS E LEIS COMPLEMENTARES}

\subsection{A Lei e seus Aspectos Gerais}

No presente capítulo, daremos fundamental atenção às leis' ${ }^{1}$, fontes formais do direito, e principalmente às leis ordinárias e leis complementares.

Fonte em direito significa aqueles órgãos ou normas de onde vem o direito, classificando-se em fonte material e formal. Fontes materiais são os órgãos que produzem o direito, como o Poder Legislativo ${ }^{2}$ a revolução ou o golpe de estado. Nos Estados

- Distinç̧ẫo, de plano, Que serve como introdução ao assunto lei, é Que na verdade a "lei é um ato normativo primário escrito, visto que o costume traduz uma normaçăo prinárla não escrita". Em essência a distinção Quanto à forma escrita traduz uma conseqüência e não a fonte da divergência. A leî, por assim dizer, é fruto da decisăo de um órgão do Estado legitimado pela Constituição. E essa decisão só se manifestará (conseqüência) para os demais, por meio de um instrumento escrito, que lhe provará a existência. O costume é o direito que passa de geração para geração, por meio de decisões tácitas num mesmo sentido, despertando a consciência de um grupo. FERREIRA FILHO, Manoel Gonçalves. Curso de direito constitucional. $30^{\mathrm{a}}$ ed. rev. e atual. São Paulo: Saraiva, 2003, p. 187. 
Democráticos de Direito, de regra, o órgão encarregado de produzir o direito é o Poder Legislativo ${ }^{3}$, composto ou não de representantes eleitos (a eleição não é condição de legitimidade democrática da representaçăo). As leịs elaboradas pelo Legislativo são as fontes formais do direito. ${ }^{4}$

Discorrendo sobre a lei em sentido formal, Hugo de Brito Machado preleciona:

Em seritido formal, lei é o ato jurídico produzido pelo Poder competente para o exercício da função legislativa, nos termos estabelecidos pela Constituição. Diz-se Que o ato tem a forma de lei. Foi feito por Quem tem competência para fazê-lo, e na forma estabelecida para tanto, pela Constituição. Nem todos os atos dessa categoria, entretanto, são leis em sentido material. ${ }^{5}$

E sobre a lei em sentido material continua o doutrinador;

Em sentido material, lei é o ato jurídico normativo, vale dizer, Que contém uma regra de direito objetivo, dotada de hipoteticidade. Em outras palavras, a lei, em sentido material, é uma prescrição jurídica hipotética, Que não se reporta a um fato individualizado no tempo e no espaço, mas a um modelo, a um tipo. É uma norma. Nem sempre as leis em sentido material também são feitas em sentido formal. ${ }^{6}$

Portanto, a palavra lei tem um sentido amploe outro restrito. Em sentido amplo, é todo ato jurídico Que se compreenda no conceito de lei ern sentido formal ou material. lá, em sentido restrito, só é lei aquela Que o seja tanto em sentido formal como em sentido material. ${ }^{7}$

As espécies normativas primárias estão previstas na Constituição Federal de 1988 (CF/88), no artigo (art.) 59, como as emendas à constituição, leis complementares, leis ordinárias, leis delegadas, medidas provisórias, decretos-legislativos e resoluções. São aquelas Que retiram seu fundamento de existência e validade diretamente da Constituição Federal de 1988, aparecendo como o primeiro nível dos atos derivados do texto constitucional. ${ }^{8}$

2 O Legislativo, ou Parlamento, como também é conhecido, pode ser unicameral e bicameral (no Brasil, o Congresso Nacional divide-se em Senado Federal e Câmara dos Deputados).

3 No direito constitucional brasileiro, como não se pode deixar de lembrar, há outras fontes matcriais do direito, como o Presidente da República, através das medidas provisórias. DifiNi, Luiz Felipe Silveira. Manual de direito tributário. São Paulo: Saraiva, 2003, p. 103.

4 DIFINI, Luiz Felipe Silveira. Manual de direito tributário. São Paulo: Saraiva, 2003, p. 103.

5 MACHADO, Hugo de Brito. Curso de direito tributário. $25^{\text {a }} \mathrm{ed}$. rev., atual. e ampl. São Paulo: Malheiros, 2004, p. 87, grifo do autor.

- MACHADO, Hugo de Brito. Curso de direito iributário. 25ª ed. rev, atual. e ampl. São Paulo: Malheiros, 2004, p. 87, grifo do autor.

7 MACHADO, Hugo de Brito. Curso de direito tributário. $25^{\mathrm{a}}$ ed. rev, atual. e ampl. São Paulo: Malleitros. 2004, p. 87.

\$ FERREIRA FILHO, Manoel Gonçalves. Curso de direito constitucional. $30^{\mathrm{a}}$ ed. rev. e atual. Săo Paulo: Saraiva, 2003, p. 184; MORAES. Alexandre de. Curso de direito constitucional. I $2^{\mathrm{a}}$ ed. São Paulo: Atlas, 2002 , p. 542. 
Sendo o Brasil uma República Federativa, composta pela União, Estados, e Municípios, coexistem no sistema jurídico ordens jurídicas parciais, a federal, a estadual, a municipal, e a nacional ou total. Então, convivem concomitantemente no sistema normativo, leis federais, estaduais e municipais, cada Qual dirigida às pessoas na Qualidade de administrados da União, Estados e Municípios, e leis nacionais, gerais. ${ }^{9}$

Da Constituição Federal dimanam conseqüências inexoráveis, como o princípio da legalidade, pelo qual ninguém pode ser obrigado a fazer ou deixar de fazer alguma coisa senão em virtude de lei. Assim, só a lei pode criar obrigações e deixar de exigi-las, pois ela é "a expressão da vontade geral, Que a tudo e a todos governa, na democracia." 10

A elaboração de Qualeuer espécie normativa deve respeitar as normas de processo legislativo " constitucionalmente previstas, para Que não acarrete a inconstitucionalidade formal do ato normativo produzido, levando, então, ao controle de constitucionalidade pelo Poder Judiciário, seja pelo método dífuso ou concentrado. ${ }^{12}$ E o processo legislativo de criação da lei vai desde a iniciativa até a publicação, passando pela votação, pelo veto e ou sanção, e a promulgação.

Em matéria tributária, a lei tem a incumbência de tratar de todos os aspectos relevantes atinentes à criação, extinção e modificação da obrigação tributária, inclusive a definição de penalidades pelo seu não cumprimento. A lei, por exemplo, descreve o fato gerador, determina a alíquota e a base de cálculo, os sujeitos ativos e passivos. ${ }^{13}$

Segundo o Código Tributário Nacional (CTN), as terminơlogias lei e legislação não se confundem, e essa distinção é de grande relevância. No CTN, a expressão lei é utilizada em seu sentido restrito, como regra jurídica geral e abstrata (sentido formal), proveniente do Poder constitucionalmente competente (sentido material). "Só é lei, portanto, no sentido em Que a palavra é empregada no CTN, a norma jurídica elaborada pelo Poder competente para legislar, nos termos da Constituição, observado o processo nesta estabelecido." ${ }^{4}$

9 RENTZSCH, Cristiane Pederzolit. Lei complementar em matéria tributária a possibilidade de revogação por lei ordinária, In: REVISTA DA FACULDADE DE DIREITO DA UNIVERSIDADE FEDERAL DO RIO GRANDE DO SUL. Porto Alegre: UFRGS, v. 21, p. 115, mar. 2002, semestral. Continuaçâo de: Revista da Faculdade de Porto Alegre, 1949-1974.

to FERREJRA FILHO, Manoel Gonçalves. Curso de direito constitucional. $30^{\mathrm{a}}$ ed, rev. e atual. São Paulo: Sazaiva, 2003, p. 280.

" "O respelito ao devido processo legislativo na elaboraçăo das espécies normativas é um dogma corolário à observância do princípio da legalidade, consagrado constitucionalmente, uma vez que ninguém será obrigado a fazer ou deixar de fazer alguma coisa, senão em virtude de espécie normativa devidamente elaborada pelo Poder competente, segundo as nomas de processo legislativo constitucional, determinando, desta forma, a Carta Magna, Quais os órgãos e quais os procedimentos de criação das normas gerais, Que determinam, como ressaltado por Kelsen 'não só os órgãos judiciais e administrativos e o processo judicial e administrativo, mas lambém os conteúdos das normas individuais, as decisóes judiciais e os atos administrativos que devem emanar dos órgãos aplicadores do direito"." MORAES, Alexandre de. Curso de direito constitucional. $12^{\text {a }}$ ed. São Paulo: Atlas, 2002, p. 524.

12 MORAES, Alexandre de. Curso de direito constitucional. $12^{\mathrm{a}}$ ed. São Paulo: Atlas, 2002, p. 524.

13 BASTOS, Celso Ribeiro. Curso de direito financeiro e de direito tributário. $5^{a}$ ed: atual. São Paulo: Saraina, 1997. p. 162.

If MACHADO, Hugo de Brito. Curso de direito tributánio. $25^{\text {a }} \mathrm{ed}$. rev., atual. e ampl. Säo Paulo: Malheiros, 2004 , p. 87-88, grifo do autor. 
lá, a palavra legislação, utilizada no art. 96, do CTN, significa leỉ em sentido amplo, abrangendo as leis em sentido restrito, os tratados, as convençöes internacionais, os decretos e as normas complementares Que versem sobre tributos etc. Aí, incluem-se, ainda, as próprias disposições da Constituição Federal de 1988, atos e leis complementares, decretosleis, convênios interestaduais e outros atos normativos sobre o assunto tributário. Veja-se, portanto, o Quanto é ampla a Questão do termo legislação em relação à lei tributária. is

Portanto, o sistema normativo tributário, muito abrangente, abarca todo o conjunto de normas usadas na área tributária, por exemplo: a) constituição e emendas; b) leis complementares; c) resoluções do Senado; d) leis ordinárias federais, estaduais e municipais; e) medidas provisórias; f) decretos, portarias, circulares, instruções normativas. ${ }^{16}$

\subsection{Requisitos Formais das Leis Ordinárias e seu Campo Material}

"A lei ordinária é ato legislativo típico." É um ato normativo primário, responsável pela edição de normas gerais e abstratas. É toda aquela que não traz o adjetivo complementar ou delegada, por exemplo, e da Qual não se exige maioria absoluta para aprovação. ${ }^{17}$.

Tocante à elaboração da lei ordinária, tem-se que é um ato complexo. Isso resulta da análise do processo de formação da lei no Direito brasileiro. Há uma fase introdutória, a dita iniciativa, uma fase constitutiva, abarcando a deliberação e a sanção e ou o veto, e a fase complementar, englobando a promulgação e a publicação. ${ }^{18}$

Quanto ao Quórum para a aprovação da lei ordinária, ele requer a maioria simples dos membros da respectiva Casa do Congresso Nacional (esta é a regra no nível infraconstitucional). Porém, a Constituição Federal de [988, art. 47, exige Quórum mínimo para a instalação da sessão, a presença da maioria absoluta dos integrantes da Casa Legislativa (Senado Federal e Câmara dos Deputados). Na verdade, esse quórum de maioria simples é variável, porque, dependendo do número de parlamentares presentes, o número se alterará. ${ }^{19}$

Exemplificando: se há noventa integrantes numa casa Legislativa e quarenta e seis estão presentes, há o Que se denomina Quórum, Que é a maioria exigida para a instalação dos trabalhos. Uma lei ordinária será aprovada se, estando presentes esses Quarenta e seis parlamentares, forem obtidos vinte e Quatro votos (metade mais um). ${ }^{20}$

15 MACHADO, Hugo de Brito. Curso de direito tributário. $25^{\circ}$ ed. rev, atual. e ampl. Săo Paulo: Malheiros, 2004 , p. 88.

${ }^{16}$ DENARI, Zelmo. Curso de direito tributário. $6^{\text {a }}$ ed. Rio de laneiro: Forense, 1998, p. 134.

i7 BASTOS, Celso Ribeiro. Curso de direito constitucional. 2 la $^{\mathrm{a}}$ ed. atual. São Paulo: Saraiva, 2000, p. 359.

is FERREIRA FILHO, Manoel Gonçalves. Curso de direito constitucional. $30^{\circ}$ ed. rev. e atual. São Paulo: Saraiva, 2003, p. 188.

MORAES. Alexandre de. Curso de direito constitucional. $12^{\mathrm{a}}$ ed. São Paulo: Atlas, 2002, p. 535.

* BASTOS, Celso Ribeiro. Curso de direito constitucional. 2 I $^{\text {a }}$ ed. atual. São Paulo: Saraiva, 2000, p. 36I, grifo do autor. 
José Afonso da Silva diz que a maioria, absoluta ou simples, é o primeiro número inteiro após a metade, seja o número de integrantes par ou ímpar, e não metade mais um. ${ }^{21}$

Como já referido ${ }^{22}$, coexistem no Brasil a ordem jurídica total ou nacional, com vigência em todo o território nacional, e as ordens jurídicas parciais, como a federal, a estadual e a municipal. Assim, a lei ordinária pode ser lei federal, aplicando-se apenas aos assuntos da União, como também pode ter caráter nacional, aplicando-se a todos os entes jurídicos e cidadãos brasileiros. ${ }^{23}$ Contudo, "em face da Constituição brasileira, o objeto da lei não é indeterminado, ou ilimitado" 24.

Quanto ao âmbito material, a lei ordinária é bem abrangente, e salvo exceçōes, ela pode tratar de Qualquer matéria ${ }^{25}$, desde Que não reservada a outra espécie normativa. Assim, não pertencem ao campo da lei ordinária os assuntos constitucionalmente reservados à lei complementar, e a outros atos normativos, como o decreto legislativo, sem falar naeuelas de competência exclusiva do Congresso Nacional (CF/88, art. 49), e nas privativas da Câmara dos Deputados e do Senado Federal (CF/88, arts. 51 e 52), pertencentes ao âmbito dos decretos legislativos e das resoluções. Porém, é comum a Constituiçăo Federal de 1988 usar apenas a expressão lei, então se diz Que esta lei é a lei ordinária. ${ }^{26}$

Destarte, há, no Direito vigente, domínio vedado à lei ordinária, além das matérias dos artigos (arts.) 49, 51 e 52, da CF/88. Por outro lado, a Constituiçáo Federal de 1988 também reserva determinados assuntos à lei ordinária, como os do art. 68, parágrafo ( $§) 1^{\circ}$, I, II e III, os Quais, inclusive, não aceitam delegação do poder de legisłar. ${ }^{27}$

No campo tributário, a lei ordinária tem papel saliente, pois conforme o CTN, art. 97, a ela cabe a instituição e extinção de tributos, sua majoração e redução; a definição do fato gerador; a fixação da base de cálculo e da alíeuota; a cominação de penalidades; as hipóteses de exclușão, suspensão e extinção dos créditos tributários no texto constitucional. ${ }^{28}$

21 SiLva, josé Afonso da. Curso de direito constitucional positivo. $23^{3}$ ed. rev. e atual. São Paulo: Maheiros, 2004, p. 517.

22. Item I.I.

${ }^{23}$ RENTZSCH, Cristiane Pederzolli. Lei complementar em matéria tributária: a possibilidade de revogação por lei ordinária. In: REVISTA DA FACULDADE DE DIREITO DA UNIVERSIDADE FEDERAL DO RIO GRANDE DO SUL. Porto Alegre: UFRGS, v. 21, p. 1/5, mar. 2002, semestral. Continuação de: Revista da Faculdade de Porto Alegre, 1949-1974.

21 FERREIRA FILHO, Manoel Gonçalves. Curso de direito constitucional. $30^{a}$ ed. rev. e atual. São Paulo: Saraiva, 2003, ค. 187.

${ }^{25}$ Agora, nem tudo é reservado à lei ordinária, assim o ato normativo ordinátio não pode imiscuir-se em Qualquer campo, porque há atos reservados à lei complementar, bem como alguns resguardados a outras fontes normativas, como o decreto legislativo. FERREIRA FILHO, Manoel Gonçalves. Curso de direito constitucional. $30^{\mathrm{a}}$ ed, rev. e atual. São Paulo: Saraiva, 2003, p. 187.

26 BASTOS, Celso Ribeiro. Curso de direito constitucional. 2 l $^{\text {a }}$ ed. atual. Săo Paulo: Saraiva, 2000, p. 360.

27 FERREIRA FILHO, Manoel Gonçalves. Curso de direito constitucional. $30^{\mathrm{a}}$ ed. rev. e atual. Săo Pauto: Saraiva, 2003, p. 188.

28 BASTOS, Celso Ribeiro. Curso de direito financeiro e de direito tributário. $5^{a}$ ed. atual. São Paulo: Saraiva, 1997, p. 162. 
Contudo, apesar do caráter de generalidade da lei ordinária, a Constituição Federal de 1988 não deixou à discricionariedade do legislador a instituiçâo de certos tributos, Que cabem à lei complementar ${ }^{29}$ : empréstimos compulsórios, contribuições de seguridade social residuais e impostos residuais $(\mathrm{CF} / 88$, arts, 148, 154, I, e 195, \$4). Isso se deve, essencialmente, à exigência da maioria absoluta nas Casas do Congresso Nacional para a aprovação da lei complementar. ${ }^{30}$

O Estado de Direito, como o brasileiro, dá suma importância à lei ${ }^{31}$, principalmente pela sujeição de tudo e todos a ela ${ }^{32}$. Nele, a importância da lei revela-se em toda sua exuberância, principalmente em razão do princípio da legalidade, de observância obrigatória tanto pelo legislador como pelo cidadão comum ${ }^{33}$. Não só em matéria tributária, mas nas obrigações em geral, a lei é a fonte por excelência do direito, o que decorre do princípio do art. $5^{\circ}, \mathrm{ll}$, da $\mathrm{CF} / 88^{34}$.

\subsection{Reouisitos Formais das Leis Complementares e seu Campo Material}

Além da lei ordinária, outro ato normativo previsto pela Constituição Federal de 1988 é a lei complementar. Contudo, o texto constitucional é lacônico e obscuro, deixando ao sabor da doutrina o seu estudo, ${ }^{35}$ Isto se verifica facilmente Quando a Constituição trata da lei complementar, propriamente dita, em apenas duas passagens: art. 59, II, e $\S$ único, e art. 69.

A previsão da lei complementar, no ordenamento jurídico nacional, surgiu com a Emenda Constitucional (EC) número (n). 4 de 1961 à Constituição de $1946^{36}$, o chamado ato adicional, instituidor do parlamentarismo Que, em seu artigo 22, permitiu a complementação do sistema parlamentar de governo com leis caracterizadas pela exigência da maioria absoluta - o Que se diga ainda é exigido -, para sua aprovação em ambas as Casas do Congresso. ${ }^{37}$

29 Ver o título reservado à lei complementar em matéria tributária, item 2. 1 .

${ }^{30}$ BASTOS, Celso Ribeiro. Curso de direito financeiro e de direito tributárlo. $5^{3}$ ed. atual. São Paulo: Saraiva, 1997, p. 163.

${ }^{31}$ Como já ressaltado Quando se tratou das leis, item 1.1.

32 FERREIRA FILHO, Manoel Gonçalves. Curso de direito constitucional. $30^{\mathrm{a}}$ ed. rev. e atual. Săo Paulo: Saraiva, 2003, p. 187.

33 BASTOS, Celso Ribeiro. Curso de direito constitucional. $21^{\text {a }}$ ed. atual. São Paulo: Saraiva, 2000, p. 360.

${ }^{34}$ BASTOS, Celso Ribeiro. Curso de direito financeiro e de direito tributánto. $5^{\mathrm{a}}$ ed. atual. Săo Paulo: Saraiva, 1997. p. 162.

${ }^{35}$ FERREIRA filHo, Manoel Gonçalves. Curso de direito constitucional. $30^{\mathrm{a}}$ ed. rev. e atual. São Paulo: Saraiva, 2003, p. 210.

36 Zelmo Denarì refere que as leis complementares surgiram com a Emenda Constitucional n. 18, de 1965, consolidadas pela Constiuluçäo de 1967, com o fim de integrar o texto constitucional c regulamentar dispositivos não auto-apilicáveis. DENARl, Zelmo. Curso de direito tributário. $6^{2}$ ed. Rio de laneiro: Forense, 1998, p. 135; DIFIN1, Luiz Felipe Silveira. Manual de direito tributário. São Pauto: Saraiva, 2003, p. II 3.

${ }^{37}$ FERREIRA FlLHO, Manoel Gonçalves. Curso de direito constitucional. $30^{\mathrm{a}}$ ed. rev. e atual. São Paulo: Saraiva, 2003, p. 210-211. 
A função clássica da lei complementar é a de completar, integrar a Constituição, pois nem todas as normas constitucionais têm o mesmo grau de aplicabilidade, podendo tornarse imediatamente eficaz. Então, é preciso uma lei capaz de lhes conferir esses elementos: aplicabilidade e eficácia. A partir da EC n. 4/196 I, instituidora do parlamentarismo, editouse uma nova modalidade de lei complementar; caracterizada não pelo seu papel de completar a Constituição, mas pelas suas características formais, ou seja, aprovação por um Quórum próprio e versar sobre matéria a ela afetada pela Constituição. Assim, pode-se dizer que há duas classificações para as leis complementares, a tradicional ou clássica, e a formal. Ambas, ainda, subsistem no ordenamento jurídico. ${ }^{38}$

A Constituição Federal de 1988 traz requisitos aos quais se submetem as leis complementares para sua edição, com o Que não resta nenhum âmbito de discricionariedade para o Poder Legislativo, relativamente a Quando e para que editá-la. As características bem definidas das leis complementares são de duas ordens: a) formal, a lei complementar deve ser aprovada por maioria absoluta (art. 69) dos membros do Congresso Nacional; b) material, a Constituição predetermina, explícita ou implicitamente, os conteúdos da lei complementar. ${ }^{39}$ Como ao primeiro se chama pressuposto formal, e ao segundo material ou ontológico, se diz Que a lei complementar tern natureza ontológico-formal ${ }^{40}$.

No mais, o processo de ejaboração da leí complementar seguirá o processo de elaboração da lei ordinária (com sanção, veto etc.) ${ }^{41}$, ou seja, o processo concernente ao ato legislativo da lei ordinária. ${ }^{42}$

Dispondo sobre o requisito da maioria absoluta ${ }^{43}$, as palavras de José Afonso da Silva:

Maioria absolutaé mais da metade, constitui-se a partir do primeiro número inteiro acima da metade, sendo erro considerá-la como metade mais um,

${ }_{38}$ BASTOS, Celso Ribeiro. Curso de direito constitucional. $21^{2}$ ed. atual. São Paulo: Saraiva, 2000, p. $358-$ 359.

39 ÁVILA, Humberto. Sistema constitucional tributário. de acordo com a emenda constitucional n. 42, de 19.12.03. São Paulo: Saraiva, 2004, p. 131.

40 CARVAl.ho, Paulo de Barros. Curso de direito tríbutário. I la ed. rev. São Paulo: Saraiva, 1999. p. 149.

41 Há quem negasse a sançăo e o veto às leis complementares, porque a própria Constituiçăo assim não prevê. É o caso, por exemplo, de Pontes de Miranda, ao tempo do ato adicional (Comentários à Constituição de 1946, v. 8, p. 177) e em face da Constituiçẩo de 67 (Comentários à Constituição de 1967, t. 3, p. 136), para Quem a aprovação da lei complementar se aperfeiçoa no Congresso. Mas a maioria da doutrina e da jurisprudência entendeu o contrário, ou seja, se a Constituiçăo năo previu é porQue se deve seguir o processo legislativo comum, com sanção e veto. FERREIRA FiLHO, Manoel Gonçalves, Do processo legishativo. $3^{a}$ ed. atual. São Paulo: Saraiva, 1995, p. 240.

42 FERREIRA FIL.HO, Manoel Gonçalves. Curso de direito constitucional. $30^{\text {a }}$ ed. rev. e atual. São Paulo: Saraiva, 2003, p. 213.

43 A maioria absoluta dos membros da Câmara dos Deputados será sempre 257 deputados, eneuanto no Senado Federal será de 41 senadores, pois esses números correspondem ao primeiro número inteiro subseqüente à divisão dos membros da Casa Legislativa (Cấmara $=513$ membros / Senado $=81$ membros). 
como não raro se ouve e se lê, visto Que será impossivel apurá-la Quando a Câmara se compuser de número ímpar de membros. ${ }^{44}$

O fato de a lei complementar ter matéria própria prevista na Constituição Federal de 1988, e só dentro deste campo ser validamente exercitável, pode levar a diferenciá-la ${ }^{45}$ das demais espécies normativas, como a lei ordinária, o decreto legislativo, a resolução, porque estas também têm matérias próprias, com campos distintos de atuação ${ }^{46}$.

Portanto, para se chegar a um conceito jurídico-positivo ou formal da lei complementar, é preciso lançar mão do Quórum especial de votação, maioria absoluta em ambas as Casas do Congresso Nacional, e do âmbito material próprio. ${ }^{47}$ Esses seriam os dois aspectos a diferenciar a lei complementar da lei ordinária: o material, com campo específico e reservado de atuação; e o formal, Que se refere ao processo legislativo na fase de votação: maioria simples para a lei ordinária, maioria absoluta para a lei complementar ${ }^{48}$.

Não se pode perder de perspectiva Que, além disso, a Constituição Federal de 1988 estabelece no art. 59, § único, Que "lei complementar disporá sobre a elaboração, redação, alteração, e consolidação das leis." ${ }^{49}$

Assim, para José Souto Maior Borges ${ }^{50}$, segundo a Teoria Geral do Direito, as leis complementares seriam de duas espécies: a) as que fundamentam a validade de outros atos normativos: b) as Que realizam a sua função constitucional independente de outras normas. Então, as Que fundamentam a validade de outras normas estariam num verdadeiro grau de hierarQuia (a hierarquia formal-procedimental) ${ }^{\text {sl }}$, superiores às demais. Ou seja, toda e Qualquer espécie normativa, com o status de leì, fica sujeita à lei complementar específica

44 SILVA, losé Afonso da. Curso de direito constitucional positivo. $23^{3}$ ed. rev. e atual. São Paulo: Malheiros, 2004 , p. 517, grifo do autor.

45 A Constituição Federal entregou a lei complementar uma matéria exclusiva, significando Que só pode dar "tratamento normativo a um campo determinado de atuação da ordem jurídica e só dentro deste ela é validamente exercitável", ou seja, separada dos demais tópicos da lei ordinária. Porém só o assunto a ser contemplado pela lei complementar não pode servir para distingui-la de outras espécies normativas, como o decreto legislativo, resoluçôes, lei delegada, e lei ordinária dos estados e municípios, já que estas também têm campo próprio de atuação. Assim, o que caracteriza esse regime peculiar é o Quórum especial de votação, conforme artigo 69, da Constituição Federal. BASTOS, Celso Ribeiro. Curso de direito financeiro e de direito tributário. 5 a ed. atual. Săo Paulo: Saraiva, [997, p. 160-161.

46 O Que inclusive já se demonstrou ao se tratar da lei ordinária, item 1.2.

47 BASTOS, Celso Ribeiro. Curso de direito constitucional. $21^{\text {a }}$ ed. atual. Săo Paulo: Saraiva, 2000 , p. 359.

48 MORAES, Alexandre de. Curso de direito constitucional. $12^{a}$ ed. São Paulo: Atlas, 2002, p. 548.

4 BRASIL. Constituição (1988). In: CONSTITUIÇÃO DA REPÚBLICA FEDERATIVA DO BRASIL: promulgada em 05 de outubro de 1988. Antônio Luiz de Toledo Pinto et. al. (col.). $3^{\text {a }}$ ed. atual. e ampl. São Paulo; Saraiva، 2004, p. 59. (Coleção Saraiva de Legislação)

50. BORGES, losé Souto Maior. Lei complementar tributária. Săo Paulo: RT, 1975, p. 54 e seguintes.

5i ÁVILA, Humberto. Sistema constitucional tributário: de acordo com a emenda constitucional n. 42, de 19.12.03. Săo Paulo: Saraiva, 2004, p. 132. 
correspondente ao art. 59, parágrafo único. ${ }^{52}$ Esta lei complementar já existe, é a de número 95, de 26.02.1998, regulamentada pelo Decreto n. 4.176, de 28.03.2002.

Como a Constituição Federal de 1988 atribui diferentes funçōes (matéria própria e forma de elaboração, redação, modificação e consolidação das leis ordinárias) às leis complementares, em razão disso elas não podem ser unitariamente descritas. ${ }^{53}$

A lei complementar, entendida como uma espécie de norma definida a partir do número de votos necessários para sua aprovação, é algo contingente, só possível de compreensão à luz do sistema jurídico Que a instituiu. ${ }^{54}$

A razão da existência da lei complementar está no fato de que o constituinte entendeu Que certas matérias, mesmo importantes, não deveriam estar na própria Constituição, sob pena de grassar suas modificações, contudo, também não poderiam ficar ào alvitre do processo legislativo ordinário. O legislador constituinte almejou agasalhar determinados assuntos infraconstitucionais de "alterações volúveis e constantes" ${ }^{55}$, mas não thes deu rigidez suficiente para impedir a modificação, Quando cogente. ${ }^{56}$ Se a Constituição Federal de 1988 traz no seu bojo, em muitos dispositivos, que a lei complementar irá tratar desta ou daquela matéria, o fez assim, pela importância dessas matérias. E só em decorrência dessas indicaçōes expressas cabe a lei complementar ${ }^{57}$.

E mais, Quanto à exigência de lei complementar feita pela Constituição Federal de 1988, parece que as decisões para a escolha de ser lei ordinária ou lei complementar são de natureza política, como o foram. A Constituição Federal de 1988 continuou exigindo lei complementar porque a Constituição anterior a 88 a exigia, ou passou a exigi-la por situações exclusivamente políticas. A decisão política é no sentido de exigir maioria Qualificada para decidir determinada matéria. Afora isto, não há nenhuma outra razão para a exigência da lei complementar. Não se pode fazer exegeses de Qualquer natureza, ou seja, tentando ler o

52 CARVALHO, Paulo de Barros. Curso de direito tributário. $11^{\mathrm{a}}$ ed. rev. São Paulo: Saraiva, 1999, p. 150 152.

53 BORGES, losé Souto Maior. Eficácia e hierarquia da lei complementar. RDP (25): 100/101, 1973; Lei Complementar Tributária. São Paulo: RT, 1975, p. 80-81. In: ÁVILA, Humberto. Sistema constitucional tributário de acordo com a emenda constitucional n. 42, de 19.12.03. São Paulo: Saraiva, 2004, p. 131-132.

54 BASTOS, Celso Ribeiro. Curso de direito financeiro e de direito tributário. $5^{\mathrm{a}}$ ed. atual. Săo Paulo: Saraiva, 1997, p. 160.

s5 Pelo bom senso, se o legislador constituinte criou um tertium genus, que é a lei complementar, o fez para "resguardar certas matérias de caráter paraconstitucional contra mudanças constantes e apressadas, sem thes imprimir rigidez que impedisse a modificação de seu tratamento, logo que necessário". Isso para não deixar ao arbítrio do legislador ordinário o que contaria ou não com essa estabilidade. FERREIRA FILHO, Manoel Gonçalves. Curso de direito constitucional. $30^{\mathrm{a}} \mathrm{ed}$. rev. e atual. São Paulo: Saraiva, 2003, p. 212; FERRE!RA FiLHO, Manoel Gonçalves. Do processo legislativo. $3^{3}$ ed. atual. São Paulo: Saraiva, 1995, p. 239.

so MORAES. Alexandre de. Curso de direito constitucional, $12^{2}$ ed. São Paulo: Atlas, 2002, p. 548.

5 FERREIRA FILHO, Manoel Gonçalves. Curso de direito constitucional. $30^{\text {a }} \mathrm{ed}$. rev. e atual. São Paulo: Saraiva, 2003, p. 212; FERREIRA FiLHO, Manoel Gonçalves. Do processo legislativo. $3^{a}$ ed. atual. São Paulo: Saraiva, 1995, p. 239. 
Que não está escrito. Se a Constituição Federal de 1988 diz lei, é lei ordinária, e não lei complementar, salvo em casos remissivos, por opção do próprio legislador constituinte. $\mathrm{Na}$ verdade, esta técnica foi usada para compor certos conflitos políticos não resolvidos pela Assembléia Nacional Constituinte, como Que numa maneira de jogar para frente. Assim, optava-se pela lei complementar ou ordinária, dependendo da matéria e do grau de controvérsia havido (excerto do voto do Min. Nelson lobim no RE 225.602-8, nov/1988). ${ }^{58}$

Portanto, o procedimento a seguir, se o da lei ordinária ou se o da lei complementar, dependerá da matéria, conforme exigência da Constituição Federal de $1988,{ }^{59}$ pois esta, enQuanto fonte normativa, não é capaz, por sí só, em alguns casos, de impor uma obrigação. "Em razão dessa incompletude, dessa carência, desse oco ou vazio normativo, passa a demandar alguma sorte de integração", por lei complementar. ${ }^{60}$

Para os doutrinadores constitucionalistas as leis complementares são aquelas que complementam os dispositivos da Constituição, desde Que não sejam auto-aplicáveis, e se Qualificam pela matéria do seu conteúdo. ${ }^{6 !}$

O âmbito de validade material da lei complementar está predeterminado constitucionalmente, ou seja, o legislador constituinte previu expressamente o que cabe ser regulado por lei complementar, escapando, portanto, ao alcance do poder legislativo ordinário $^{62}$. A lei complementar não pode contradizer a Constituição Federal de 1988. Não é outra forma de emenda constitucional, embora desta se aproxime em razão da matéria e da exigência da maioria Qualificada. Mas como Qualeuer outra espécie normativa primária pode incidir em inconstitucionalidade e ser, por isso, inválida ${ }^{63}$.

S8 PAULSEN, Leandro. Direito tributário. constituição e código tributário à luz da doutrina e da jurisprudéncia. $6^{\text {a }}$ ed. rev. atual. Porto Akgre: Livraria do Advogado: ESMAFE, 2004, p. 97.

59 MORAES, Alexandrc dc. Curso de direito constitucional. $12^{\text {a }}$ ed. São Paulo: Atlas, 2002, p. 549.

6) BASTOS. Cesso Ribeiro. Curso de diréto financeiro e de direito tributário. $5^{a}$ ed. atual. São Paulo: Saraiva, 1997, p. 159.

5 CARVALHO, Paulo de Barros. Curso de diretto tributário. $11^{\text {a }}$ ed. rev. São Paulo: Saraiva, 1999. p. 149.

52 COÊLHO, Sacha Calmon Navarro. Comentários à Constituif̧ão de 1988: sistema tributário. $7^{\text {a }}$ ed. Rio de laneiro: Forense, 1998, p. 114.

63 FERREIRA FILHO, Manoel Gonçatves. Curso de direito constitucional. $30^{2}$ ed. rev. e atual. São Paulo: Saraiva, 2003, p. 211-212; FERREIRA FILHO, Manoel Gonçalves. Do processo legishatívo. $3^{\text {a }}$ ed. atual. Sâo Paulo: Saraiva, 1995, p. 238. 


\section{LEIS COMPLEMENTARES EM MATÉRIA TRIBUTÁRIA E A SUPOSTA HIERAROUIA ENTRE A LEI COMPLEMENTAR E A LEI ORDINÁRIA EM FACE DA CONSTITUIÇÃO FEDERAL DE 1988}

\subsection{Leis Complementares em Matéria Tributária}

Antes de adentrar no assunto lei complementar em matéria tributária, esclarecimento importante para aQueles não tão afeitos ao Direito Tributário é o Que se refere às normas complementares e leis complementares. Estas últimas têm a função de completar a Constituição, enquanto aquelas (art. 100, CTN) sâo formalmente atos administrativos e materialmente leis, ou seja, compreendem-se dentro da expressão legislação tributária (art. 96. CTN). Em essência, as normas complementares completam o texto das leis, tratados e convençōes internacionais e decretos. Se completam, não podem inovar ou modificar. ${ }^{64}$

Especialmente às leis complementares de conteúdo tributário, como toda e qualquer lei complementar, são entes legislativos, caracterizados por sua forma e matéria, ou forma e fundo. Formalmente, a lei complementar é aquela votada por maioria absoluta. Sob o ponto de vista material, a lei complementar objetiva complementar a Constituição, seja normatizando ou operacionalizando os seus comandos. ${ }^{65}$ Esses requisitos, portanto, "formam a técrica de reconhecimento das leis complementares tributárias no sistema jurídico brasileiro"66.

No campo tributário, a Constituição Federal de 1988 reserva duas funções para a lei complementar: a de complementar as disposições constitucionais e a excepcional de criar tributos. Na Constituiçẫo Federal de 1988, a função de completá-la é tríplice, conforme os incisos do art. 146, compreendendo dispor sobre conflito de competência, em matéria tributária, entre a União, os Estados, o Distrito Federal e os Municípios; regular as limitações constitucionais ao poder de tributar; e estabelecer normas gerais de direito tributário. Mas, como a disciplina gera! do sistema tributário está no texto constitucional, a lei complementar deve detalhá-lo, conforme seus limites. A lei complementar deve explicar o que está impícito na Constituição, completando e não emendando o conteúdo que o próprio texto constitucional prevê, conforme Pontes de Miranda, ainda na vigência da Constituição Federal de $1967 .{ }^{67}$

64 MACHADO, Hugo de Brito. Curso de direito tributário. $25^{\mathrm{a}}$ ed. rev., atual. e ampl. São Paulo: Matheiros, 2004, p. 97.

${ }^{65}$ COÊLHO, Sacha Calmon Navarro. Comentários à Constituição de 1988: sistema tributário. $7^{\text {a }}$ ed. Rio de Janeiro: Forense, 1998, p. 113.

60 COÊlHO, Sacha Calmon Navarro. Comentários à Constituição de 1988: sistema tributário. $7^{\text {a }} \mathrm{ed}$. Rio de laneiro: Forense, 1998, p. 119.

67 RENTZSCH. Cristiane Pederzolli. Lei complementar em matéria tributária a possibilidade de revogaçăo por lei ordinária. In: REVISTA DA FACULDADE DE DIREITO DA UNIVERSIDADE FEDERAL DO RIO GRANDE DO SUL. Porto Alegre: UFRGS, v. 21, p. 114, mar. 2002, semestral. Continuação de: Revista da Faculdade de Porto Alegre, 1949-1974. 
Como a Constituição Federal de 1988 delineou o perfil do sistema tributário nacional, identificando cada espécie tributária, e impondo os limites ao poder de tributar, cabe à lei complementar ditar as regras gerais destes tributos, a fim de dar uniformidade ao regramento básico da obrigação tributária e a todo o sistema tributário nacional. ${ }^{68}$

Confira-se com os ensinamentos de Sacha Calmon Navarro Coelho:

A lei complementar é utilizada, agora sim, em matéria tributária para fins de complementação e atuaçâo constitucional. (A) Servem para complementar dispositivos constitucionais não auto-aplicáveis (not self executing), i. é.. dispositivos constitucionais de eficácia limitada, na terminologia de José Afonso da Silva. (B) Servem ainda para conter dispositivos constitucionais de eficácia contida (ou contíve)). (C) Servem para fazer atuar determinaçóes constitucionais consideradas importantes e de interesse de toda a Nação. Por isso mesmo as leis complementares requisitam Quorum Qualificado, por causa da importância naciona/das matérias postas à sua disposição. ${ }^{69}$

Nesta seara, as leis complementares desempenham o importante "papel de uniformizar critérios legislativos para instituição de tributos". Como são regras de observância obrigatória, mesmo Que editadas pela União, guardam o caráter de leis nacionais ${ }^{70}$, pois vinculam até o legislador federal. Na verdade, os destinatários da norma não são os administrados, mas o legislador, em cada nível de governo - lei para o legislador -.$^{71}$

A principal norma constitucional em matéria tributária é a do art. 146, Que requer lei complementar para tratar dos assuntos ali previstos ${ }^{72}$. Sobre o art. 146, caput, Leandro Paulsen não discrepa da maioria doutrinária, ou seja, para se saber se é ou não necessária lei

68 RENTZSCH, Cristiane Pederzolli. Lei complementar em matéria tributária. a possibilidade de revogação por lei ordinária. In: REVISTA DA FACULDADE DE DIREITO DA UNIVERSIDADE FEDERAL DO RIO GRANDE DO SUL. Porto Alegre: UFRGS, v. 21, p. 114, mar. 2002, semestral. Continuação de: Revista da Faculdade de Porto Alegre, 1949-1974.

69 COÊLHO. Sacha Calmon Navarro. Comentários à Constituiçăo de 1988: sistema tributário. $7^{a}$ ed. Rio de laneiro: Forense, 1998, p. 118, grifo do autor.

to Leis nacionais ou totais são aquelas Que abrangem todos os entes federativos, União, Estados, Distrito Federat e Municípios, e leis federais săo aquełas que săo de observância obrigatória apenas para a União (item (.1).

7 DENARI, Zelmo. Curso de direito tributário, $6^{\text {a }}$ ed. Rio de laneitro: Forense, 1998, p. 135.

n Só a leì complementar pode: l) tratar conflitos de competência, em matéria tributária, entre União, Estados, Distrito Federal e Municípios; (I) regular as limitaçōes constitucionais ao poder de tríbutar; 1Il) estabelecer normas gerais em matéria de legislação tributária, especialmente sobre; a) definiçăo de tributos e de suas espécies, bem como, em relaçăo aos impostos discriminados nesta Constituição, a dos respectivos fatos geradores, bases de cálculo e contribuintes; b) obrigaçăo, lançamento, crédito, prescrição e decadência tributários; c) adequado tratamento tribulário ao ato cooperativo praticado pelas sociedades cooperativas; d) definição de tralamento diferenciado e favorecido para as microcmpresas e para as empresas de pequeno porte, inclusive regimes especiais ou simplificados no caso do imposto previsto no art. 155, II, das contribuiçôes previstas no art. 195, 1 e §§ 12 e 13, e da contribuição a que se refere o art. 239. BRASIL. Constituição (1988). In: CONSTITUIÇÃ̃O DA REPÚBLICA FEDERATIVA DO BRASIL: promulgada em 05 de outubro de [988. Antônio Luiz de Toledo Pinto et. a!. (col:). $33^{\text {a }}$ ed. atual. e ampl. São Paulo: Saraiva, 2004, p. 97-98. (Coleção Saraiva de Legislação) 
complementar para dispor sobre determinada matéria, tem-se que analisar o texto constitucional, pois a lei complementar só é indispensável se aQuele expressamente a requer. ${ }^{73}$

Embora o art. 146, da CF/88, seja importante, não é o único a prever a exigência da lei complementar. Ainda, são várias as normas constitucionais em matéria tributária que exigem lei complementar, exemplificando ${ }^{74}:$ a) art. 146- $\mathrm{A}^{75}$; art. 148 ; b) art. 149, observado o disposto nos artigos 146, III, 150, I e lll, e sem prejuízo do previsto no art. $195, \S 6^{\circ}$; c) art. 150. VI, "c"; d) art. 153, Vll; e) art. 154, l, para o caso de impostos não previstos no art. 153, da própria Constituição; f) art. 155, §1 ${ }^{\circ}$, Ill; g) art. 155, $\$ 2^{\circ}, X$, "a", XII; h) art. 156, Ill, desde Que não compreendidos no art. $155,11, \S 3^{\circ}$; i) art. 156, §3; j) art. $(61 ; 1)$ 195, §11.76

Logo, se a Constituiçẫo Federal de 1988 diz lei complementar, a matéria só por esta pode ser tratada, conforme Leandro Paulsen:

A Constituição elenca, expressamente, as matérias cuja disciplina se dará em caráter complementar à Constituição, através de veículo legislativo próprio, Que exige quorum qualificado, a lei complementar. Para sabermos se é ou não necessária lei complementar para dispor sobre determinada matéria, temos, pois, de analisar o texto constitucional; só é necessária lei complementar Quando a Constituiçăo expressamente a reQuer. ${ }^{77}$

${ }^{73}$ PAULSEN, Leandro. Dircito tributário: constituição e código tributário à luz da doutrina e da jurisprudência. $6^{2}$ ed. rev. atual. Porto Alegre: Livraria do Advogado: ESMAFE, 2004, p. 96.

${ }^{7 / 4}$ Usa-se a expressão exemplificando porque o presente trabalho não tem por objeto esgotar a matéria, e pode ter escapado ao campo de vista algum assunto em matéria tributária a ser regulamentado por lei complementar.

75 Artigo 146-A, da Constituição Federal de 1988, inserido pela Emenda Constitucional n. 42, de 19.12.2003. BRASIL. Constituiçăo (1988). In: CONSTITUIÇÃO DA REPÚBLICA FEDERATIVA DO BRASIL: promulgada em 05 de outubro de 1988. Antônio Luiz de Toledo Pinto et. al. (col.). 33a ed. atual. e ampl. Săo Paulo: Saraiva, 2004, p. 98. (Coleção Saraiva de Legislaçăo)

\% Procurou-se incluir as altełações sofridas pela Constituição Federal de 1988 até a Emenda Constitucional n. 42. RENTZSCH, Cristiane Pederzolli. Lei complementar em matéria tributária a possibilidade de revogação por lei ordinária. In: REVISTA DA FACULDADE DE DIREITO DA UNIVERSIDADE FEDERAL DO RIO GRANDE DO SUL. Porto Alegre: UFRGS, v. 21, p. 114, mar. 2002, semestral. Continuação de: Revista da Faculdade de Porto Alegre, 1949-1974; ROSA JúNIOR, Luiz Enygdio F. da. Manual de direito Inanceiro e direito tributario. $11^{\mathrm{a}} \mathrm{ed}$. atual., ampl. Rlo de laneiro: Renovar, 1997. p. 166-167.

77 PAULSEN, leandro. Direito tributário. constituiçấo e código tributário à luz da doutrina e da jurisprudência. $6^{\text {a }}$ ed. rev. atual. Porto Alegre: Livraria do Advogado: ESMAFE, 2004, p. 96. Leandro Paulsen cita, nesse sentido, decisão do STF: Plenário, ADin 2.028, Rel. Min. Moreira Alves, nov/1999. D/U de 16.06.2000, p. 30: "De há muito se firmou a jurisprudência desta Corte no sentido de que só é exigível lei complementar Quando a Constituição expressamente a ela faz alusão com referência a determinada matéria, o Que implica dizer que cuando a Carta Magna alude genericamente a 'lei' para estabelecer princípio de reserva legal, essa expressão compreende tanto a legislação ordinária, nas suas diferentes modalidades, Quanto a legislação complementar." (PAULSEN, Leandro. Direito tributário constituição e código tributário à luz da doutrina e da jurisprudência. $6^{\mathrm{a}}$ ed. rev. atual. Porto Alegre: Livraria do Advogado: ESMAFE; 2004, p. 96). 


\subsection{A Suposta Hierarouia entre Lei Complementar e Lei Ordinária em Face da Constituição Federal de 1988}

Procurar-se-á clarear o enredo sobre a hierarquia constitucional de leis, ou melhor, se há hierarquia entre lei complementar e lei ordinária no ordenamento jurídico nacional ${ }^{78}$. No rol da Constituição Federal de 1988, art. 59, não há QualQuer espécie de hierarquia entre as espécies normativas, ainda mais que todas têm por fundamento de validade a própria Constituição. O fato de a lei complementar estar prevista antes da lei ordinária não a fáz superior. ${ }^{79}$ Tanto Que, salta à baila o fato da medida provisória, por própria determinação consitucional, deter o status de lei ordinária, nada obstante o fato de constar abaixo dela no rol do art. 59. da $\mathrm{CF} / 88$.

Diante das colocações anteriore ${ }^{80}$ Quanto às leis ordinárias e as leis complementares, tira-se que as diferenças entre elas são de duas categorias: material e forma ${ }^{81}$. Materialmente, só pode ser objeto de lei complementar a matéria taxativamente prevista na Constituiçăo Federal de 1988, todas as demais serão objeto de lei ordinária, se não prevista outra espécie normativa. Quanto à forma, ou melhor, à fase de votação no processo legislativo, o Quórum para aprovação da lei ordinária é de maioria simples (art. 47, CF/88), ao passo Que a lei complementar requer maioria absoluta para aprovação da matéria (art. 69, CF/88) ${ }^{82}$

Com base no Quórum de aprovação, a doutrina tradicional situa as leis complementares num plano inferior à Constituição Federal de 1988, mas superior às leis ordinárias. Contudó, tal posição vem sendo contestada pela doutrina mais moderna, Que as considera no mesmo plano, apenas com diversidade de matérias. As matérias reservadas pela Constituição à lei complementar não podem ser regradas ou alteradas por lei ordinária, pelo simples fato da reserva legislativa. ${ }^{83}$

78 Enfatize-se que o direito positivo é o complexo de normas jurídicas válidas num dado país, enquanto à ciência do direito cabe descrever esse enredo normativo, ordenando-o, declarando sua hierareuia. CARVALHO, Paulo de Barros. Curso de diretio tributário. $1 \mathrm{I}^{2}$ ed. rev. São Paulo: Saraiva, 1999, p. 1.

7 Com o Que não concorda, atualmente, Paulo de Barros Carvalho. RENTZSCH, Cristiane Pederzolli. Lei complementar em matéria tributária: a possibilidade de revogação por lei ordinária. In: REVISTA DA FACULDADE DE DIREITO DA UNIVERSIDADE FEDERAL DO RJO GRANDE DO SUL. Porto Alegre: UFRGS, v. 21, p. 117, mar. 2002, semestral. Continuação de: Revista da Faculdade de Porto Alegre, 1949-1974.

$\infty$ Capítulo 1, itens 1.2 e 1.3 .

81 Em nosso ordenamento há leis ordinárias e leis complementares. Distinguem-se do ponto de vista "substancial" ou material, e formal. Do ponto de vista "substancial", as leis complementares se identificam porque a Constituição diz expressamente os casos por elas a serem regulados (exemplificando, artigos 146,148 , 153. Vll, 154, 1). Quanto ao aspecto formal, além de ter numeração própria, a lei complementar exige Quórum especial, maioria absoluta, para sua aprovação (artigo 69. Constituição Federa). MACHADO, Hugo de Brito. Curso de direito tributário. $25^{\mathrm{a}}$ ed. rev., atual. e ampl. São Paulo: Malheiros, 2004, p. 88.

2. MORAES. Alexandre de. Curso de direito constitucional. $12^{3}$ ed. São Paulo: Atlas, 2002, p. 548-549.

a DIFINI, Luiz Felipe Silveira. Manual de direito tributário. São Paulo: Saraiva, 2003, p. 1/4. 
Em certos casos, a Constituição Federal de 1988 exige lei complementar

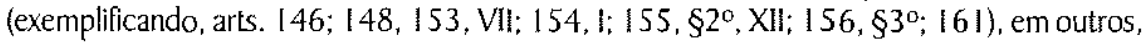
ela se refere simplesmente à expressão lei, sem dizer se complementar ou ordinária. Para o Supremo Tribunal Federal (STF), na ausência de menção expressa a Qual tipo de lei, trata-se de lei ordinária, mas há contrariedade ${ }^{84}$. Porém, a Questão não é assim tão simples. Por exemplo, o art. 150, Vl, "c", in fine, cuida de imunidade "das instituições de educação e de assistência social, sem fins lucrativos, atendidos os requisitos da ler". Qual lei? Como a Constituição Federal de 1988 não diz, poder-se-ia falar lei ordinária. Contudo, o art. I46, Il, $\mathrm{da} \mathrm{CF} / 88$, refere caber à lei complementar regular as limitaçōes constitucionais ao poder de tributar. E imunidade é limitação constitucional ao poder de tributar, o Que está expresso no art. 150, Vl. É caso de aplicação da interpretação sistemática. ${ }^{85}$

Portanto, há posições doutrinárias dizendo que lei complementar só por lei complementar é modificável, estivesse ou não a matéria reservada à Lei de tal nível. ${ }^{86}$ Isto significa Que, se uma matéria não reservada à lei complementar pela Constituição Federal de 1988, por ela fosse regulada, não poderia ser modificada por QualQuer outra espécie normativa, Que não a lei complementar.

Sobre a exigência ou não de lei complementar pela Constituição Federal de 1988, o STF tem dito Que, se era despicienda a lei complementar, mas por esta se deu a fonte legislativa, recepcionada como let ordinária será, mantendo apenas o status formal de lei complementar, portanto plenamente possível a modificação por lei ordinária ${ }^{87}$

87 De regra, os assuntos rescrvados pela constituiçăo à leỉ complementar estão Quase sempre expressos. embora, algumas vezes, se encontre a alusão apenas à expressão lei. Nesses casos, seguindo a grandeza do tema (constilucional), pode-se concluir que é a lei complementar. CARVALHO, Paulo de Barros. Curso de direito tributário. I la ed. rev. Săo Paulo: Saraiva, 1999. p. 149.

${ }^{85}$ DIFINI, Luiz Felipe Silveira. Manual de direito tributário. Săo Paulo: Saraiva, 2003, p. 115.

* Conforme Manuel Gonçalves Ferreira Filho citando Miguel Reale e Pontes de Miranda. "Náo é só, porém, o argumento de autoridade oue apóia essa tese; a própria lógica jurídica o faz. A lei complementar só pode ser aprovada por maioria Qualificada, a maioria absoluta, para Que năo seja, nunca, o fruto da vontade de uma minoria ocasionalmente em condiçócs de fazer prevatecer sua voz. Essa maioria ć assim um sinal certo da maior ponderação que o constituinte Quis ver associada ao seu estabclecimento. Paralelamente, deve-se convir, não Quis o constituinte deixar ao sabor de uma deçsão ocasional a desconstituição daquilo para cujo estabelecimento exigiu ponderação especial. Alás, é princípio geral de direito Que, ordinariamente, um ato só possa ser desfeito por outro que tenha obedecido à mesma forma. $\mathrm{Da}$ inserção da lei complementar entre a Constituição $\mathrm{c}$ a lé ordinária, decorrem conseqüências inexoráveis e óbvias." FERREIRA FILHO, Manoel Gonçalves. Curso de direito constitucional. $30^{\text {a }}$ ed. rev. e atual. São Paulo: Saraiva, 2003, p. 211 ; FERREIRA FILHO, Manoel Gonçalves. Do processo kgislativo. $3^{a}$ ed. atual. Săo Paulo: Saraiva, 1995, p. 238.

87 Portanto, apesar de várias vozes em sentido contrário, há julgados dando pela possibilidade de revogaçäo por lei ordinárịa da isenção - no caso da Lei 9.430/96, artigo 56, Que revogou a isenção da Colins para as socicdades civis prestadoras de serviços profissionais de profissão regulamentada - instituída por lei complementar, sob o fundamento de que a isenção năo é matéria de lei complementar (TRF4, $2^{a}$ T., unânime, MAS 2001.71.05.007199-0/RS, rel. Des. Fed. João Surreaux Chagas, set/2002). PAULSEN, Leandro. Direito Tributário: constituição e código tributário à luz da doutrina e da jurisprudência. $6^{\mathrm{a}}$ ed. rev. atual. Porto Alegre: Livraria do Advogado: ESMAFE, 2004, p. 98. 
Nesse diapasão, Leandro Paulsen:

As leis buscam seu suporte de validade diretamente na Constituição Federal. Se a Constituição não exige lei complementar, tem-se Que a lei ordinária pode validamente dispor sobre a matéria, não sendo pertinente QualQuer comparação com o veículo legislativo anteriormente utilizado. Não é o equivocado e desnecessário tratamento de certa matéria em lei complementar Que vai colocá-la, daí para diante, sob reserva de lei complementar, eis que a própria Constituição é Que estabelece o Que lhe será complementar. A idéia de hierarquia entre lei complementar e lei ordinária, pois, é relativa. A lei ordinária simplesmente não pode afrontar lei complementar nas matérias a esta reservadas, pois não constituirá, nesse caso, veículo legislativo apto a inovar na ordem jurídica Quanto a aQueles pontos. ${ }^{88}$

Com a falta de hierarquia discordam alguns doutrinadores, pois para eles a lei complementar é formalmente superior às demais leis, estando diretamente abaixo da Constituição Federal, o Que decorreria do fato da necessidade da maioria absoluta para sua aprovação $0^{89}$. Ao longo do tempo esta corrente perdeu forças, reconhecendo a falta de Qualquer superioridade hieráruica da lei complementar frente à lei ordinária, em face do art. 59. da $\mathrm{CF} / 88 .^{90}$

Se uma lei complementar regular matéria, por exemplo, reservada à lei ordinária, não será inconstitucional, apenas incorrerá em Queda de status ${ }^{91}$, valendo como lei ordinária. Isto é assim, porque se leva em conta a identidade do órgão legislativo ${ }^{92}$ emitente da lei: Quem

\& PAULSEN, Leandro. Direito Tributário: constituição e código tributário à luz da doutrina e da jurisprudência. $6^{\mathrm{a}} \mathrm{ed}$ rev. atual. Porto Alegre: Livraria do Advogado: ESMAFE, 2004, p. 97.

DIFINI, Luiz Felipe Silveira. Manual de direito tributário. Säo Paulo: Saraiva, 2003, p. 115.

${ }^{\infty}$ Geraldo Ataliba (Lei complementar na constituição. São Paulo: RT, 1971, p. 30) reconhecia a hierarquia entre lej complementar e lei ordinária, porém inlluenciado por losé Souto Maior Borges seus estudos não prosperaram e ele reconheceu a falta de superioridade. $\mathrm{RENTZSCH}$, Cristiane Pederzolli. Lei comp/ementar em matéria tributária. a possibilidade de revogação por lei ordinária: In: REVISTA DA FACULDADE DE DIREITO DA UNIVERSIDADE FEDERAL DO RIO GRANDE DO SUL. Porto Alegre: UFRGS, v 21, p. 1 16, mar. 2002, semestral. Continuação de: Revista da Faculdade de Porto Alegre, 1949-1974.

91 A lei complementar busca seu requisito de validade na própria Constituição Federal, ou melhot, só é contrastável frente à Lei Maior. Se vier a regular matérias teservadas aos Estados e Municípios, por exemplo. não valerá, sendo inconstitucional por invasão de competência, sofrendo o fenômeno da rejeiçãão. O mesmo ocorre se a lei ordinária invade o campo reservado para a lel complementar. Agora, se lei complementar regular matéria reservada à let ordinária, aquela sofre Queda de status, ou fenômeno da adaptação: o sistema adapta a lei em razão da matéria, năo da forma. Quanto aos fenômenos, há, ainda, o da recepção, Que nada mais é do que o reconhecimento da lei pelo sistema, em razão da sua existência, validade formal e material. e assim, sua vigência e eficácia. COÊLHO, Sacha Calmon Navarro. Comentários à Constituição de 1988 sistema tributário. $7^{\text {a }}$ ed. Rio de laneiro: Forense, 1998, p. 119-120.

22 Acaso a lei complementar regule matéria reservada aos Estados e Municípios, por exemplo, será inconstitucional por invadir a compctência particular. Mas se regular matéria da Uniâo que caberia à lei ordinária, sofrerá apcnas urna Queda de status, vigorando como lei ordinária. Isto só ocorre em razão da identidade de órgãos legislativo responsável pela edição de qualquer uma das espécies normativas. E também não haverá QualQuer irregularidade 
pode o mais, pode o menos ${ }^{93}$. A recíproca não prevalece: Quem pode o menos, não pode o mais. A lei ordinária excederá de sua competência se cuidar de matéria reservada à lei complementar, sendo inválida. ${ }^{94}$

Pontualmente, Luiz Felipe Silveira Difini ${ }^{95}$ possui entendimento diverso:

A nosso ver, a lei complementar tem maior hierarouia que a lei ordinária, poreue formalmente diferenciada pela Constituição, com processo legislativo com maiores exigências. A matéría só poderá ser regrada por lei complementar quando a Constituição assim dispuser expressamente ou tal resultar de sua interpretação sistemática (então será inválida, por afrontar a Constituição, seu trato pela lei ordinária). Não ocorrendo essas hipóteses, à opção do legislador, a disciplina poderá ser feita por lei complementar ou ordinária. Se o legislador optar pela lei complementar; com maiores exigências formais, esta não poderá ser modificada ou revogada por lei ordinária, para a Qual as exigências formais são menos rígidas, do Que decorre menor hierarquia legislativa. A tese de Que não sendo a matéria expressamente reservada, pela Constituição, à lei complementar, eventual lei complementar que sobre eła verse pode ser alterada por lei ordinária, não tem supedâneo na Constituição e gera grave instabilidade jurídica. Não é razoável que lei complementar, para cuja aprovação se exige maioria absoluta, possa ser alterada por lei ordinária, aprovada por maioria simples. ${ }^{96}$

formal na edição da lei. Ela apenas não será materiałmente complementar, mas formalmente, pois o Quórum Qualificado, por si só, não altera a substância do instrumento. A recíproca não prospera, ou seja, lei ordinária Que tratar de matéria reservada à lei complementar será inconstitucional. RENTZSCH. Cristiane Pederzolli. Lei complementar em matéria tributária. a possibilidade de revogaçăo por lei ordinária. In: REVISTA DA FACULDADE DE DIREITO DA UNIVERSIDADE FEDERAL DO RIO GRANDE DO SLiL. Porto Alegre: UFRGS, v. 21, p. 116 , mar. 2002, semestral. Continuação de: Revista da Faculdade de Porto Alegre, 1949-1974.

${ }^{93}$ COELHO, Sacha Calmon Navarro. O controle de constitucionalidade das leis e do poder de tributar ha constituição de 1988. Ed. Del Rey, 1992. In: PAULSEN, Leandro. Direito tributário. constituição e código tributário à luz da doutrina e da jurisprudência. $6^{2}$ ed. rev. atual. Porto Alegre: Livraria do Advogado: ESMAFE, 2004, p. 98.

* COELHO, Sacha Calmon Navarro. Comentários à Constituç̧ăo de 1988: sistema tributário. $7^{\text {a }}$ ed. Rio de laneiro: Forense, 1998, p. 119.

9s Apesar de divergir de Luiz Felipe Silveira Difini, como já ficou acima trasladado, Leandro Paulsen não deixa de mencionar a posiçăo contrária: "O 5Tl, contudo, na esteira da orientação esposada por Hugo de Brito Machado, tem entendìdo, ao abordar a revogação de dispositivo da Lei Complementar n. 70/91 pela Lei Ordinária n. 9.430/96, no sentido da existência de hierarquia entre ambas, afizmando que lei ordinária não pode revogar lei complementar, seja qual for a matéria nesta tratada." PAULSEN, Leandro. Direito tributário. constituiçăo e código tributário à luz da doutrina e da jurisprudência. $6^{a}$ ed. rev. atual. Porto Alegre: Livraria do Advogado: ESMAFE, 2004, p. 97.

* DIFIN, Luiz Felipe Silvetra. Manual de direito tributário. São Paulo: Saraiva, 2003, p. 115. 
Porém, "segundo respeitável doutrina, inexiste hierarquia entre lei complementar e lei ordinária, já que ambas possuem campos de atuação diversos. Em decorrência, pode ocorrer invasão de competência, não ofensa ao princípio da hierarquia das leiss." ${ }^{97}$ Resta, portanto, saber se a lei em Questão ${ }^{98}$ necessitava ou não ser lei complementar ${ }^{99}$, como é o caso da Lei Complementar n. 70/91, instituidora da COFINS.

\section{COFINS E A REVOGAÇÃO DA ISENÇÃO PARA AS SOCIEDADES CIVIS DE PROFISSIONAIS LIBERAIS}

\subsection{COFINS e suas Características}

A COFINS - Contribuição para o Financiamento da Seguridade Social - foi criada pela Lel Complementar n. 70/91, com base na redação original do art. 195, 1, da CF/88, em 31 de dezembro de 1991. A COFINS originou-se como contribuição social sobre o

97 RENTZSCH, Cristiane Pederzolli. Lei complementar em matéria tributaria, a possibilidade de revogação por lei ordinária. In: REVISTA DA FACULDADE DE DIREITO DA UNIVERSIDADE FEDERAL DO RIO GRANDE DO SUL. Porto Alegre: UFRGS, v. 21, p. 116. mar. 2002, semestral. Continuação de: Revista da Faculdade de Porto Alegre, 1949-1974.

28 "Porianto, de acordo com a posição doutrinária majoritária, a Qual acolhemos, não há propriamente uma hierarquia entre as leis, apenas cada uma tem seu campo de atuaçảo especfifico, no Qual é autônoma e absoluta." RENTZSCH, Cristiane Pederzolli. Lei complementar em matéria tributária: a possibilidade de revogaçăo por lei ordinária. In: REVISTA DA FACULDADE DE DIREITO DA UNIVERSIDADE FEDERAL DO RJO GRANDE DO SUL. Porto Alegre: UFRGS, v. 21, p. 117; mar. 2002, semestral. Continuação de: Revista da Faculdade de Porto Alegre, 1949-1974.

\% "Tributário. Retroatividade de Lei mais Benéfica. Limitaçăo Temporal. Lei Complementar. O Tribunal negou provimentio a recurso extraordinário interposto pelo Instituto Nacional do Seguro Social - INSS contra acórdăo do TRF da $4^{\text {a }}$ Regiäo que, com base no inciso [l do art. 106 do CTN, mantivera sentença na parte em que aplicara 0 art. 35 da Lei $8.212 / 91$, com a redação dada pela Lei $9.528 / 97$, a fatos pretéritos, em razão de a mesma prever pena de multa, sobre contribuiçóes sociais em atraso, menos severa Que a cominada anteriozmente, e a「astara a incidência da limitação temporal prevista no caput do referido art. 35 , tendo em conta a declaração, incidenter tantum, de sua inconstitucionalidade, pela Corte Especial daquele Tribunal, por ofensa ao inciso lil do art. 146 da CF (Lei 8.2 [2/91, com a redaçăo dada pela Lei 9.528/97: Art. 35. Para os fatos geradores ocorridos a partir de $1^{\circ}$ de abril de 1997 , sobre as contribuiçốes sociais em atraso, arrecadadas pelo INSS, incidirá multa de mora, Que năo poderá ser relevada, nos seguintes termos:'): Salientou-Se; inicialmente, o caráter exemplificativo do inciso lll do art. 146 da CF, que prevế competir à lei complementar estabelecer normas gerais sobre matéria de legislação tributária. Entendeu-se estar a multa tributária inserta no campo das nornas gerais, a eual, por isso, deve ser imposta de forma linear em todo território nacional, 'não se fazendo com especificidade limitadora geograficamente'. Concluju-se Que a Lei 8.212/91, ao impor restrição temporal ao benefício de redução da nłulta, acabou por limitar regra da lei complementar (CTN, art. 106, 11), violando o disposto na alínea b do inciso lll do art. 146 da CF. Dessa forma, declarou-se a inconstitucionalidade da expressão "para os fatos gezadores ocorridos a partir de $1^{\circ} \mathrm{de}$ abril de $1997^{\circ}$, constante do caput do art. 35 da Lei 8.212/91, com a redação dada pela Lei 9:528/97." BRASIL. Supremo Tribunal Federal. Recurso Extraordinário n. 407.190/RS. Pleno. Relator: Min. Marco Aurélio. Brasília, 27 de outubro de 2004. In: Informativo 367, STE Disponível em: <www.stf.gov.br/ noticias/informativos/anteriores/in[0367.asp». Acesso em: 28 mar. 2005, grifo no original. 
faturamento, substituindo o tributo de mesma destinação constitucional, o FINSOCIAL, cobrado até a entrada em vigor daquela, conforme art. 56, do Ato das Disposiçôes Constitucionais Transitórias (ADCT $)^{100}$.

No cenário jurídico nacional, as contribuições sociais surgiram com a Constituição Federal de 1934 Que, no art. $121, \$ 1^{\circ}$, alínea "h", dispunha sobre a previdência social, fazendo menção expressa à cobrança de "contribuição igual da União, do empregador e do empregado, a favor da velhice, da invalidez, da maternidade e dos casos de acidente do trabaiho ou da morte". Naquela época, entretanto, a contribuição ainda era inominada. ${ }^{10 t}$

Atualmente, as contribuições sociais são instituídas pela União ${ }^{102}$ com base nos arts. 149 e 195, da Constituição Federal de 1988. ${ }^{103}$ As contribuições sociais, sendo uma subespécie de contribuições especiais (em contraponto às contribuições de melhoria), por sua vez, já foram denominadas, também, de contribuiçōes parafiscais - esta nomenclatura encontra-se em desuso ${ }^{104} 105$.

A atual classificação da COFINS decorre da divisão das espécies tributárias no direito brasileiro, Quais sejam: impostos, taxas, contribuições de methoria, empréstimos compulsórios e contribuições especiais. Então, as contribuições sociais são uma subespécie de contribuiçôes especiais que, por sua vez, divide-se em:

a) contribuições especiais;

a. I) contribuiçōes sociais;

a. I. 1) gerais (art. 149, primeira parte, $\mathrm{CF} / 88$ );

a. i.2) de seguridade social;

a. 1.2.1) nominadas (art. 149, primeira parte $\mathrm{c} / \mathrm{c}$ art. 195, 1, 11, III, CF/88),

a. 1.2.2) residuais (art. 149, primeira parte $\mathrm{c} / \mathrm{c}$ art. $195, \S 4^{\circ}, \mathrm{CF} / 88$ ),

a. 1.2.3) de previdência do funcionalismo público estadual, distrital e municipal (art. $149, \S 1^{\circ}, \mathrm{CF} / 88$, conforme EC $41 / 2003$ ),

a.2) de intervenção no domínio econômico (art. 149, segunda parte, CF/88);

a.3) de interesse das categorias profissionais ou econômicas (art. 149, terceira parte, $\mathrm{CF} / 88$ );

\footnotetext{
100 ÁVILA, René Bergmann. PORTO, Éderson Garin. Cofins. Porto Alegre: livraria do Advogado, 2005, p. 13.

${ }^{101}$ DENARI, Zelmo. Curso de direito tributário. $6^{\mathrm{a}}$ ed. Rio de Janeiro: Forense, 1998, p. 107-108.

${ }^{102}$ A titularidade para a instituição das contribuições sociais, ou previdenciárias, é exclusiva da União, afơa a exceção do art. 149 , $1^{\circ}$, da $\mathrm{CF} / 88$, que também a dá aos Estados, Distrito Federal e Municípios, para a instituição de contribuição de sistemas de previdência ou assistência social, cobrada dos seus servidores, e revertida em benefício destes. Mas os Estados, Distrito Federal e Municípios não podem criar outras contribuiçóes sociais, como a União, exigiveis de outros sujeitos passivos, Que não servidores efetivos. DIFINI, Luiz Felípe Silveira. Manual de direito tributário. São Paulo: Saraiva, 2003, p. 52.

${ }^{103}$ CHIMENTI, Ricardo Cunha. Direito tributário. $5^{\text {a }}$ ed. São Paulo: Saraiva, 2002, v. 16, p. 49. (Coleção Sinopses Jurídicas)

${ }^{104}$ PAULSEN, Leandro. Direito tributárior. constituição e código tributário à luz da doutrina e da jurisprudência. $6^{a}$ ed. rev. atual. Porto Alegre: Livraria do Advogado: ESMAFE, 2004, p. $41-43$, e 139.

${ }^{105}$ DIFIN!, Luiz Fełipe Silveira. Manual de direito tributário. Săo Paulo: Saraiva, 2003, p. 50.
} 

$39 / 2002){ }^{106}$

a.4) de iluminação pública municipal e distrital (art. 149-A, CF/88, conforme EC n.

Portanto, diante do Quadro apresentado, a COFINS situa-se no campo das contribuições especiais, sendo uma contribuição social, de seguridade social e nominada.

Antes da Constituição Federal de 1988, muito se discutiu se as contribuições sociais eram ou não tributos, sujeitando-se aos princípios inerentes a eles. A doutrina ${ }^{107}$ reconhecia-lhes caráter tributário, ao passo Que o fisco dizia Que não eram tributos, com fundamento de que esses estavam previstos no art. $[8$, da $\mathrm{CF} / 69$, ao passo que as contribuiçôes no art. 21 , $\S 2^{\circ}$, l, da mesma Carta. ${ }^{108}$

A Constituição Federal de 1988 trata das contribuições sociais no Título Vl (Da Tributação e do Orçamento) Capítulo I (Do Sistema Tributário Nacional), fazendo expressas remissões no ant. 149, caput, "observado o disposto nos arts. 146. III, e I 50, I e III", o Que esclarece estarem as contribuições sociais sujeitas às normas gerais de direito tributário (art. 146, III) e aos princípios da legalidade (art. 150, 1) e da irretroatividade e anterioridade (art. 150, III, a be $c$ ). A Constituição Federal de 1988 também prevê expressamente a exceção: "sem prejuizo do previsto no art. $195, \S 6^{\circ}$, relativamente às contribuições a que alude o dispositivo". Portanto, as contribuições sociais para financiamento da seguridade social como a COFINS - só podem ser exigidas noventa dias - anterioridade mitigada ou nonagesimal - após a publicação da lei Que as instituiu ou aumentou, sem aplicação do princípio da anterioridade (só pode ser exigida no ano seguinte à publicação da lei). ${ }^{109}$

${ }^{106}$ PAULSEN, Leandro. Direito tributário. constituição e código tributário à luz da doutrina e da jurisprudência. $6^{\mathrm{a}}$ ed. rev. atual. Porto Alegre: Livraria do Advogado: ESMAFE, 2004, p. 43.

107 "As contribuiçōes enquanto tributos. Histórico. As contribuições passaram a ser consideradas tributos por força da EC n. 01/69, Que estabeleceu, ao lado da competência da União para instituir impostos, sua competência para instituir contribuiçóes de intervenção no domínio econômico, de interesse da previdência social e do interesse de categorias profissionais, conforme se vê do art. $21, \$ 2^{\circ}, 1, \mathrm{CF} / 67 \mathrm{com}$ a redação da EC n. 01/69, situado dentro do Capítulo V - Do Sistema Tributário Nacional. Com a EC n. 08/77, porém, emboła a previsão da competência da Unnião para instituir contribuiçöes tenha permanecido dentro do capítulo atinente ao Sistema Tributário Nacional, houve o acréscimo do inciso $X$ ao art. 43, que cuídava da competência legislativa da Uniáo, passando a constar, separadamente, a competência legislativa para dispor sobre tributos, arrecadação e distribuição de rendas (inciso l) e para dispor sobre contribuições sociais (inciso X). Tal foi suficiente para que o STF entendesse Que o Constituinte havia entendido não serem, as contribuições, tributos. A Constituição de 1988, por fim, deu-lhes tratamento dentro do Sisterna Tributário Nacional e, escoimando Qualquer dúvida, estabeleceu que thes seriam aplicadas limitaçōes constitucionais ao poder de tributar, bem como as normas gerais em matéria tributária (art. 149 com remissão ao art. 146, 111)." PAULSEN, Leandro. Direito tributário. constituição e código tributário à luz da doutrìna e da jurisprudência. $6^{\bar{a}}$ ed. rev. atual. Porto Alegre: Livraria do Advogado: ESMAFE, 2004, p. 138, grifo do autor.

${ }^{108}$ DIFINI, Luiz Fełipe Silveira. Manual de direito tributário. São Paulo: Saraiva, 2003, p. 50.

${ }^{\omega}$ DENAR, Zelmo. Curso de direito tributário. $6^{\mathrm{a}}$ ed. Rio de laneiro: Forense, 1998, p. 110-111; DIFIN!, Luiz Felipe Sitveira. Manual de direito tributário. São Paulo: Saraiva, 2003, p. 51; MACHADO, Hugo de Brito. Curso de direito tributário. $25^{\mathrm{a}}$ ed. rev., atuał. c ampl. Săo Paulo: Malheiros, 2004, p. 398. 
Diante da clareza do Texto Constitucional, a polêmica doutrinária sobre se as contribuiçôes sociais são ou não tributos esmaeceu, restando apenas um interesse especulativo e sem Qualeuer importância prática ${ }^{110}$. Não se pode perder de perspectiva Que a maioria da doutrina considera as contribuiçôes como tributos, reforçando a tese o fato de estarem sujeitas às disposições constitucionais tributárias"'". Como tributo, as contribuições são uma categoria à parte, nem imposto, nem taxa ${ }^{12}$, com critério específico de validação $e$ disciplina inconfundível, e se eualificam, principalmente, pela finalidade Que buscam alcançar. ${ }^{1 / 3}$

Portanto, resta induvidosa a natureza tributária dessas contribuiçồes, e a identificação da natureza jurídica de eualeuer imposição do Direito é importante, pois acaba por definir Quais as normas jurídicas aplicáveis. ${ }^{114}$

A Constituição Federal de 1988, art. 149, enumera as causas para a criação das contribuiçōes especiais, Que são, portanto, tributo especia/por ser afetado a finalidades predeterminadas na Constituição Federal de 1988 - seguridade social, intervenção no domínio econômico e interesse de categorias profissionais ou econômicas ${ }^{1 / 5}$. Contudo.

' ${ }^{10}$ MACHADO, Hugo de Brito. Curso de direito tributário. 25 ed. rev, atual. e ampl. Săo Paulo: Malheiros. 2004, p. 398.

"II DIFIN1, Luiz Felipe Silveira. Manual de direito tributário. São Pauło: Saraiva, 2003, p. 51.

${ }^{112}$ No Brasil, a doutrina considerou as contribuiçóes paraliscais como tributo, que nos dizeres de Becker "as contribuiçóes parafiscais não constituem uma natureza jurídica de tributo suigeneris, mas tributo de natureza mista, porque, em determinados casos, são simples impostos com destinação determinada e, noutros, verdadeiras taxas". Justifica o seu entendimento afirmando Que a destinação do tributo, a sua maior ou menor proporçăo (em relaçăo à base de cáiculo) e a posição do sujeito passivo em relaçăo à hipótese de incidência do tributo não exercem qualquer influêncta sobre a natureza jurídica do tributo. A. Theodoro Nascimento, por sua vez, examinando a contribuiçăo parafiscal sob a égide da EC n. $1 / 69$, considerou-a como imposto especia/pelas seguintes razóes: "Entendemos que no sistema tributário brasileiro a parafiscalidade é imposto especial, consociativo ou corporativo, com aquelas características que Sax e Tangorra assinalaram: exigido dos Que compōem categorias econômicas e profissionais para custear serviços Qưe atendem necessidades especiais experimentadas pelos grupos aos Quais os contribuintes pertencem. A essa categoria tributária Que, sobreposta aos impostos gerais, ordinários, atinge grupos profissionais e econômicos que tiram maior proveilo de determinados serviços, criados para atender necessidades especiais deles, o legislador brasileiro denominou de contribuição parafiscal". ROSA lúNıOR, Luiz Emygdio F. da. Manual de direito financeiro e direito tributário. $\left[1^{2}\right.$ ed. atual. e ampl. Rio de laneiro: Renovar, 1997, p. 401-402, grifos do autor.

${ }^{13}$ PAULSEN, Leandro. Direito tributário. constituição e código tributário à luz da doutrina e da jurisprudência. $6^{a}$ ed. rev. atual. Porto Alegre: Livraria do Advogado: ESMAFE, 2004, p. 141.

${ }^{1 / 4}$ MACHADO, Hugo de Brito. Curso de direito tributário. $25^{\mathrm{a}} \mathrm{ed}$. rev., atual. e ampl. São Paulo: Mahheiros, 2004, p. 398.

${ }^{1 / 5}$ DENARI, Zelmo. Curso de direito tributário. $6^{\mathrm{a}}$ ed. Rio de laneiro: Forense, 1998, p. 110-1 11; É de bom alvitre frisar que enquanto a CF/88 próbe a vinculação de impostos a lim determinado (art. 167, IV, com as exceçōes previstas no próprio dispositivo), as contribuiçóes têm, por essência, sua destinaçăo, com exclusividade, aos fins específicos, o Que está previsto na legislação Que as institui. Aqui, Quem sabe, o mais importante traço de diferença entre contribuiçōes e impostos, pois naqueles não há necessariamente uma contraprestação específica em favor do contribuinte que as satisfaz (ao contrário das taxas). Tome-se como exemplo a contribuição previdenciária a cargo do empregador, mas Que será revertida para o empregado. DIFINI, Luiz Felipe Silveira. Manual de direito tributário. Săo Paulo: Saraiva, 2003, p. 52; DENARI, Zelmo. Curso de direito tributário. $6^{\mathrm{a}}$ ed. Rio de Janeiro: Forense, 1998, p. 114; MACHADO. Hugo de Brito. Curso de direito tributário. $25^{\text {a }}$ ed. rev., atual. e ampl. Săo Paulo: Malheiros, 2004, p. 398. 
essas causas não consubstanciam hipóteses de incidência, o Que caberá à lei Que instituir as contribuições especiais. Importa é Que a finalidade justifica a instituição da contribuição especial, como critério de validação constitucional de sua cobrança. O próprio STF já decidiu (RT) 85/926, 85/70I, 92/252, 93/1.217) Que as contribuições especiais correspondem a uma modalidade autônoma, ou heterônoma ${ }^{116}$, de tributo, com tratamento diferente do dado aos impostos, taxas ou contribuições de melhoria ${ }^{117}$.

Pode-se dizer Que, no Direito positivo nacional, em face da Constituiçāo Federal de 1988, o conceito de contribuição especial ganhou um elemento importante para a sua formação, principalmente no tocante aos limites do poder de tributar. Segundo o art. 149, as contribuiçôes especiais caracterizam-se pela correspondente finalidade - Que induz a idéia de vinculação direta -, e não pela simples destinação do produto da respectiva arrecadação. ${ }^{118}$

Hugo de Brito Machado discorre sobre a finalidade das contribuições especiais:

Admitir uma espécie de contribuiçōes sociais para cuja instituição bastaria a fustificativa de um fim social é um equívoco, pois todo e qualquer tributo tem sempre, ou deve ter, finalidade social, de sorte Que a finalidade social não pode ser um elemento capaz de dar oualificação específica a uma contribuição. A finalidade social Qualifica o gênero tributo. Não a espécie contribuições. Muito menos uma subespécie de contribuições. ${ }^{119}$

A contribuição especial a Que se dará fundamental importância é a COFINS, uma contribuição de seguridade social - e esta também é a sua finalidade -, de regime jurídico bem definido na Constituição Federal de 1988, arts. 195, I, Il e lll, e $\$ 6^{\circ}, 165$, §5, e 194 , $\S$ único, VII. 20

Num primeiro momento, a COFINS era cobrada sobre o faturamento das empresas. sem prejuízo das demais contribuições sociais incidentes sobre a folha de salários e o lucro. Após algum tempo, modificou-se a base de cálculo da COFINS, passando ela a incidir sobre a receita - conceito mais amplo do Que faturamento -, e atualmente sobre a receita menos

${ }^{116}$ DENAR!, Zelmo. Curso de direito tributário. 6a ed. Rio de laneiro: Forense, 1998, p. $115-116$.

${ }^{177}$ ROSA JÚNIOR, Luiz Emygdio F. da. Manual de direito financeiro e direito tributário. 1 la ed. atual. e ampl. Rio de Janeiro: Renovar, 1997, p. 405.

${ }^{118}$ MACHADO, Hugo de Brito. Curso de direito tributário. $25^{\mathrm{a}} \mathrm{ed}$. rev., atual. e ampl. São Paulo: Malheiros, 2004 , p. 397.

119 MACHADO, Hugo de Brito. Curso de direito tributário. $25^{3} \mathrm{ed}$. rev, atual. e ampl. São Paulo: Malheiros, 2004, p. 398.

${ }^{120}$ MACHADO, Hugo de Brito. Curso de direito tributário. $25^{\mathrm{a}}$ ed. rev., atual. e ampl. São Paulo: Malheiros. 2004, p. 402; ROSA JúNIOR, Luiz Emygdio $\mathrm{F}$ da. Manual de direito financeiro e direito tributário. $1^{\text {a }}$ ed. atual. e ampl. Rio de Janeiro: Renovar, 1997, p. 404. 
alguns valores ${ }^{12 !}$, diante da não-cumulatividade. Ressalva deve ser feita Que esta última forma de cobrança abrange somente algumas pessoas jurídicas, logo há duas bases de cálculo da contribuição Que detém pouco de seu feitio limiar: o nome. ${ }^{122}$

A COFINS sofreu inúmeras alterações constitucionais desde a sua criação em 199 I, com a Lei Complementar n. 70, e conseoüentemente legais, abrangendo assim diversos aspectos, como base de cálculo, sujeitos passivos, isençōes, etc. Com isso, a jurisprudência dos tribunais superiores - Supremo Tribunal Federal e Superior Tribunal de Justiça (ST|) também sofreu inúmeras modificações ao longo dos anos. ${ }^{123}$

Apesar de as contribuições sociais do art. 195, 1, da CF/88 se individualizarem, pelo fato de serem definidas pelas finalidades a Que estão predispostas - financiamento da seguridade social, como saúde, previdência e assistência social $\_{ }^{124}$, não se pode confundir a finalidade com destinação dos recursos no plano fático ${ }^{125}$. As contribuições de seguridade social, como a COFINS, deveriam constituir receita no orçamento da seguridade, de que trata o art. $165, \S 5^{\circ}$, III, da CF/88. ${ }^{i 26}$

Contudo, o sujeito ativo das contribuições de seguridade social não precisa ser necessariamente o Instituto Nacional de Seguridade Social (INSS), ou seja, a própria União (Tesouro Nacional) pode cobrar o tributo - sujeito ativo -. O STF ${ }^{127}$ tem decidido pela

:2t A Cofins foi instituída pela Lei Complementar n. 70/91, euie extinguiu o Finsocial regulado pelo DecretoLei n. 1940/82, e é cobrada sem prejuízo das contribuiçôes para o PIS/PASEP, tem por base de cálculo a receita bruta mensal das pessoas jurídicas (observadas as exclusões do IPI, das vendas canceladas e dos

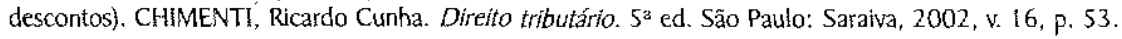
(Coleção Sinopses furídicas)

${ }^{122}$ ÁVILA, René Bergmann. PORTO, Éderson Garin. Colins. Porto Alegre: Livraria do Advogado, 2005, p. 13.

${ }^{123}$ ÁVILA, René Bergmann. PORTO, Éderson Garin. Cofins. Porto Alegre: Livraria do Advogado, 2005, p. 14.

${ }^{124}$ BASTO5, Celso Ribeiro. Curso de direito financeiro e de direito tributário. $5^{\text {a }}$ ed. atual. São Paulo: Saraiva, 1997, p. 155.

${ }^{125}$ PAULSEN, Leandro. Direito tributário: constituição e código tributário à luz da doutrina e da jurisprudência. $6^{\mathrm{a}}$ ed. rev. atual. Porto Alegre: Livraria do Advogado: ESMAFE, 2004, p. 140.

${ }^{126}$ MACHADO, Hugo de Brito. Curso de direito tributário. $25^{\text {a }}$ ed. rev., atual. e ampl. Săo Paulo: Malheiros, 2004, p. 399.

${ }^{127}$ O entendimento esposado pelo STF vai no sentido de levar o debate para o campo do Direito Financeiro, Diretto Administrativo e/ou Direito Penal. Sustenta-se que a regra do art. $165, \S 5^{\circ}, \mathrm{CF} / 88$, é de Direito Financeiro, o Que denota não poder ser argüido descumprimento do dispositivo legal para ilidir o pagamento do tributo. Se as verbas não tomaram o rumo da finnalidade para Que foram criadas, a responsabitidade é dos administradores, e portanto eles é Que devem ser punidos. Segundo voto (ll. 455 do acórdạo, p. 9 do voto) do Ministro Carlos Velloso (no julgamento do RE 138.284-CE, julgado em 01.07.1992, Tribunal Pleno, DJ 28.08. (992, p. 13.456) bastaria, para a instituição da contribuição, Que o destino da verba fosse a Seguridade Social, embora notória a destinação dos recursos ao orçamento da União. Mesmo respeitável a decisão do STF; não se pode perder de perspectiva que a $\mathrm{CF} / 88$ refere expressamente serem as contribuições instituídas com uma linalidade, sendo o produto da arrecadaçăo vinculado. A finalidade da Colins é custear a seguridade social, se isso não ocorrer, a validade da cobrança pode ser questionada. Portanto, se năo levado em conta um atributo constitucional de validade das contribuições, este é um assunto tributário e não Pinanceiro. ÁVILA, René Bergmann. PORTO, Éderson Garin. Cofins. Porto Alegre: Livraria do Advogado, 2005, p. 15-16; PAULSEN, Leandro. Direito tributário. constituição e código tributário à luz da doutrina e da jurisprudência. $6^{a}$ ed. rev. atual. Porto Alegre: Livraria do Advogado: ESMAFE, 2004, p. 141-142. 
possibilidade de cobrança da COFINS pela União, como sujeito ativo, desde Que se apliQue os recursos em saúde, assistência social e previdência - finalidade -. ${ }^{128}$ Assim, pouco importa a destinação dos recursos, ou seja, Quem é o sujeito ativo, desde Que seja mantida a finalidade da contribuiçãa ${ }^{129}$.

Contribuintes da COFINS são as pessoas jurídicas de direito privado, e as a elas equiparadas pela legislação do imposto de renda; conforme previu inicialmente o art. $1^{\circ}$, Lei Complementar n. 70/91 e legislação posterior. Segundo o art. $1^{\circ}$, são contribuintes da COFINS "toda pessoa jurídica, ou outra entidade a ela equiparada pela legislação do imposto de renda, Que aufira 'receita' através da venda de mercadorias, mercadorias e serviços ou serviços de Qualeuer natureza (artigo $2^{\circ} \mathrm{da} \mathrm{LC}$ n. 70/91)."

Por sua vez, a legislação esparsa ora exclui, ora inclui (contribuintes) determinadas pessoas jurídicas em razão de certas pecullaridades. A própria Constituição Federal de 1988 sofreu alterações, senão vejamos. A redação do inciso 1, art. 195, até a EC n. 20/98, de 16.12.1998, à Constituição Federal de 1988 era: I-dos empregadores, incidente sobre a folha de salários, o laturamento e olucro. Após a emenda: I- do empregador, da empresa e da entidade a ela equiparada na forma da lei, incidentes sobre. Dita alteração ampliou o rol de contribuintes, deixando de ser apenas os empregadores, passando a abarcar empresas e entidades a ela equiparadas na forma da lei ${ }^{13 !}$. A alteração só ocorreu poreue as pessoas jurídicas não-empregadoras também eram cobradas pela exação. porém a Constituiçāo Federal de 1988 não as incluía, o Que era inconstitucional. Assim, a partir da emenda, a COFINS pode ser exigida tanto das pessoas jurídicas empregadoras como das não-empregadoras. ${ }^{132}$

Pertinente aos contribuintes da COFINS, tenha se em mente que o art. $6^{\circ}$, II, da Lei Complementar $n .70 / 91^{133}$ isentou as sociedades civis de prestação de serviços profissionais

\footnotetext{
${ }^{128}$ MACHADO, Hugo de Brito. Curso de direito tributário. $25^{\mathrm{a}} \mathrm{ed}$. rev., atual. e ampl. São Pauto: Malheiros, 2004 , p. 403.

129 PAULSEN, Leandro. Direito tributário constituição e código tributário à luz da doutrina e da jurisprudência. $6^{a}$ ed. rev. atual. Porto Alegre: Livraria do Advogado: ESMAFE, 2004, p. 140.
}

${ }_{130}$ ÁVILA, René Bergmann. PORTO, Éderson Garin. Colins, Porto Alegre; Livraria do Advogado, 2005, p. 33.

${ }^{131}$ Analisando o inciso l, do art. 195, CF/88: a) dos empregadores, da empresa e da entidade a cla equiparada (há decisões no sentido de Que a expressão empregadores atinge também aquefes que remuneram serviços prestados sem vínculo empregatício); b) da folha de salários e demais rendimentos do trabalho pagos ou creditados, a Qualeuer tútulo, à pessoa física Que preste serviços, mesmo sem vínculo empregatício (inclui os avulisos e os autônomos): e, c) sobre a receita e o faturamento. CHIMENTI, Ricardo Cunha. Direito tributário. $5^{\text {a }}$ ed. São Paulo: Saraiva, 2002, v. 16, p. 51 . (Coleção Sinopses lurídicas)

${ }^{132}$ ÁVILA, René Bergmann. PORTO, Éderson Garin. Collns. Porto Alegre: Livraria do Advogado, 2005, p. $33-36$.

133 "Art. $6^{\circ}$ São isentas da contribuição:

$[\ldots]$

II - as sociedades civis de Que trata o art. $1^{\circ}$ do Decreto-Lei n. 2.397 , de 21 de dezembro de $1987 . "$ BRASil. Lei Complementar n. 70, de 30 de dezembro de 199 !. Instituí contribuição para financiamento da Seguridade Social, eleva a alíeurota da contribuição social sobre o lucro das instituiçöes financeiras, e dá outras providências. Diário Oficial da Uniâo, Brasília, 31 de dezembro de 1991. Disponível em: swww.senado.gov.br/sf/legislação/legislà. Acesso em: 28 mar. 2005. 
relativos ao exercício de profissão legalmente regulamentada - as ditas Sociedades Civis (de advogados, médicos, contadores etc.) - do seu recolhimento, independentemente do regime jurídico do imposto sobre a renda adotado (lucro real ou presumido).

Entretanto, em 1996, a Lei Ordinária n. 9.430, art. 56 $6^{134}$, revogou expressamente a dita isenção. Veja-se que a isenção foi instituída por lei complementar, por outro lado, a revogaçăo deu-se por lei ordinária. A par disso, o fisco passou a exigir dita contribuição.

Conseqüentemente, adentraram no judiciário muitas ações Questionando a nova cobrança, baseadas, fundamentalmente, no fato de Que lei ordinária não pode revogar assunto disciplinado por lei complementar, em razão da hierarquia das leis, de cunho constitucional.

\subsection{A Revogação por Lei Ordinária da Isenção da Cofins para as Sociedades Civis de Profissionais Liberais Instituída por Lei Complementar}

O assunto da revogação da isenção da COFINS para as Sociedades Civis de Profissionais Liberais não é estritamente legal, mas tema da suposta hierarouia constitucional de leis. Isto porque, com a nova disposição legal, o debate passou a ser em torno da validade constitucional da alteração da lei complementar através de lei ordinária. Para isso, deve-se levar em conta, principalmente, se a matéria - COFINS - é ou não reservada à lei complementar. ${ }^{135}$. De regra, os euestionamentos da nova cobrança, basearam-se, principalmente, no fato de que a lei ordinária não pode revogar assunto disciplinado por lei complementar, em razão da hierarquia constitucional das leis.

Partir-se-á da premissa Que não há propriamente hierarquia ${ }^{136}$ no Sistema Tributário Constitucional entre lei ordinária e lei complementar, mas sim, matérias reservadas à lei

134 “Art. 56. As sociedades civis de prestação de serviços de profissäo legalmente regulamentada passam a contribuir para a seguridade social com base na receita bruta da prestação de serviços, observadas as normas da Lei Complementar n. 70, de 30 de dezembro de 1991. Parágrafo único. Para efeito da incidência da contribuiçấo de que trata este artigo, serão consideradas as receitas auferidas a partir do mês de abril de 1997." BRASIL. Lei n. 9.430, de 27 de dezembro de 1996. Dispöe sobre a legislação tributária federal. as contribuiçóes para a seguridade social, o processo administrativo de consulta e dá outras providências. Diáro Oficial da União, Brasilia, 30 de dezembro de 1996. Disponivel em: «www.senado.gov.br/sf/legislaçäo/ legislar. Acesso em: 28 mar. 2005.

${ }^{135}$ ÁVILA, René Bergmann. PORTO, Éderson Garin. Cofins. Porto Alegre: Livraria do Advogado, 2005, p. 73.

136 "Em suma, entendemos que não existe no sistema juridico brasileiro hierarquia entre as normas tegais, uma vez Que todas possuem como seu fundamento de validade a Constituição Federal e estão a ela subordinadas diretamente. Existe apenas a reserva da lei complementar, a Qual afasta a possibilidade de outros veículos normativos versarem sobre determinadas matérias." RENTZSCH, Cristiane Pederzolli. Lei complementar em matéria tributária. a possibilidade de revogação por lei ordinária. In: REVISTA DA FACULDADE DE DIREITO DA UNIVERSIDADE FEDERAL DO RIO GRANDE DO SUL, Porto Alegre: UFRGS, v. 21, p. 119. mar. 2002, semestral. Continuaçäo de: Revista da Faculdade de Porto Alegre, 1949-1974. 
complementar e outras tratáveis por lei ordinária ${ }^{137}$. Além de Que, o problema não se refere ao simples tema de isenção tributária, o Qual não é matéria de reserva da lei complementar, ou melhor, tem cunho residual, podendo ser objeto de lei ordinária ${ }^{138}$.

Resta saber se a Cofins, instituída com base no art. 195, I, da CF/88, exigia ou não lei complementar para sua criação. René Bergmann Ávila e Éderson Garin Porto trazem a posição do STF, segundo o Qual a contribuição da Lei 7.689, de 15.12.88, é uma contribuiçấo social instituída com base no art. 195, I. da Constituição Federal de 1988, não exigindo, para sua instituição, lei complementar. Apenas a contribuição do $\$ 4^{\circ}$ do mesmo art. 195 é Que exige lei complementar, dado Que essa instituição deverá observar a competência residual da União (CF, art. 1.95, §4 $4^{\circ}$; CF, art. 154, I). Por não estarem sujeitas à lei complementar do art. 146, Ill, da CF/88, porque não são impostos ${ }^{139}$, não há necessidade de que a lei complementar defina seu fato gerador, base de cálculo e contribuintes (CF, art. I46, III, a). ${ }^{140}$

E concluem os doutrinadores:

Por outro lado, em diversos acórdãos, o Supremo Tribunal Federal já declarou Que a criação de conțribuiçôes sociais somente exige lei complementar no caso de contribuição prevista no $\$ 4^{\circ}$ do art. 195 da Constituição Federal: às contribuiçôes previstas nos incisos do caput desse mesmo dispositivo, a matéria é de lei ordinária. E a lei complementar, por tratar de matéria de lei ordinária, embora formalmente seja lei complementar, materialmente é leỉ ordinária. Dessa lógica desenvolvida pelo STF, chega-se à conclusão de Que a Lei Complementar n. 70/9l é materialmente lei ordinária, e, por isso, pode ser alterada por outra lei ordinária; no caso, a Lei $9.430 / 96$, Que revogou a isenção anteriormente concedida pela Lei Complementar n. $70 / 9 !^{14 !}$

${ }^{13 \%}$ Conforme Nota de Rodapé n. 1 10. ÁVIIA, René Bergmann. PORTO, Éderson Garin. Cofins. Porto Alegre: Livraria do Advogado, 2005, p. 74.

${ }^{138}$ RENTZSCH, Cristiane Pederzolli. Lei complementar em matéria tributáriar a possibilidade de revogação por lei ordinária. In: REVISTA DA FACULDADE DE DIREITO DA UNIVERSIDADE FEDERAL DO RIO GRANDE DO SUL. Porto Alegre: UFRGS, v. 21, p. 118, mar. 2002, semestral. Continuaçăo de: Revista da Faculdade de Porto Alegre, 1949-1974.

139. Diante do art. 146, 111, "a", $\mathrm{CF} / 88$, Que dispöe caber à lei complementar estabelecer normas gerais em matéria tributária, principałnente sobre definição de tributos e suas espécies, bem como, em relação aos impostos discriminados na $\mathrm{CF}_{*}$ a dos respectivos fatos geradores, bases de cálculo e contribuintes. $\mathrm{O}$ dispositivo deixa evidente que, somente em relação ao impostos discriminados na CF/88, a lei complementar tem competência para determinar o fato gerador, a base de cálculo e os contribuintes. O STF, pelo Pleno, julgamento do RE n. 138.284-CE (RT 143/313), por unanimidade, decidiu Que as contribuiçőes sociais não são impostos. Como não são impostos não se aplica a exigência do art. 146, Ill, "a", CF/88 (Essa também a conclusão do Tribunal Regional Federal da $5^{2}$ Região no julgamento da Apelação em Mandado de Segurança n. 90.0501681/CE, Rel. luiz losé Delgado, D1 07.06.1991, p. 13081). ÁVILA, René Bergmann. PORTO, Éderson Garin. Colins. Porto Alegre: Livraria do Advogado, 2005, p. 73-74.

${ }^{140}$ Conforme Nola de Rodapé n. 6, descrevendo o Recurso Extraordinário n. 138.284-CE, julgado em 01.07. [992. Tribunal Pleno, D] 28.08.1992, p. 13.456. In: ÁVILA, René Bergmann. PORTO, Éderson Garin. Colins. Porto Alegre: Livraria do Advogado, 2005, p. 15-16.

¿4l ÁVILA, René Bergmann. PORTO, Éderson Garin. Cofins. Porto Alegre: Livraria do Advogado, 2005 , p. 74. 
Logo, importante é a definição pelo STF da natureza jurídica dos dispositivos da Lei Complementar n. 70/91, Qual seja, se a matéria, tratada por lei cujo processo legislativo observado tenha sido a lei complementar, não seja daQuelas para Qual a Constituição Federal de 1988 exige essa espécie legislativa, os dispositivos Que tratam dela se têm como dispositivos de lei ordinária. ${ }^{142}$

No julgamento do Recurso Extraordinário (RE) n. 150.764-1/PE (Plenário, julgado em 16.12.92. Relator Ministro Marco Aurélio, por maioria - RT| |47/ 1024), ratificou-se a idéia de Que a lei ordinária pode alterar lei sobre as contribuições do ínciso I, art. 195, CF/88. Nessa perspectiva, o RE n. 146.733-9/SP (julgado em 29.06. 1992, Relator Ministro Moreira Alves, DJU 06.11.1992, unânime), julgamento do egrégio STF confirmando a desnecessidade da lei complementar para a instituição da contribuição do art. 195, I, da CF/88. ${ }^{143}$

Para René Bergmann Ávila e Éderson Garin Porto, a decisão da Ação Direta de Constitucionalidade n. I-1/DF também é importante, pois trata especificamente da Cofins, apesar de não se manifestar propriamente Quanto à revogação ou não da isenção:

Veio então a julgamento da Ação Direta de Constitucionalidade n. 1/DF (STF, Plenário. j. 10.12.92, e 16.12.1992, Rel. Min. Moreira Alves, Diu 16.06.95). Ao contrário dos acórdãos anteriores, Que tratavam de outras contribuições sociais, a ADC I $^{144}$ tratou especificamente da constitucionalidade da COFINS. 145

${ }^{142}$ ÁVILA, René Bergmann. PORTO, Éderson Garin. Cofins, Porto Alegre: Livraria do Advogado, 2005. p. 26.

143 ÁVILA, René Bergmann. PORTO, Éderson Garin. Cofins. Porto Alegre: Livraria do Advogado, 2005. p. 19.

${ }^{144}$ Vei̧a-se parte do voto do Min. Moteira Alves (item 5), na ADC I: "Por isso mesmo, essa contribuição poderia ser instituída por Lei Ordinária. A circunstância de ter sido instituída por lei formalmente complementar - a Lei Complementar n. 70/91 - näo hhe dá, evidentemente a natureza de contribuição social nova, a Que se aplicaria o disposto no $\varsigma^{\circ}$ do artigo 195 da Constituição, porquanto essa lei, com relação aos dispositivos concernentes à contribuição social por ela instituída - Que são o objeto desta ação -- é materialmente ordinária, por não se tratar, nesse particular, de matéria reservada, por texto expresso da Constituição, à lei complementar. A jurisprudência desta Corte, sob o império da Emenda Constitucional n. 1/69 - c a Constituição atual não alterou esse sistema -, se firmou no sentido de que só se exige lei complementar para as matérias cuja disciplina a Constituição expressamente faz tal exigência, e, se porventura a matéria, disciplinada por lei cujo processo legislativo observado tenha sido o de lei complementar, não seja daquelas para que a Carta Magna exige essa modalidade legislativa, os dispositivos que tratam dela se têm como dispositivos de lei ordinária. Näo estando, portanto, a COFIN5 sujeita às proibições do inciso I do artigo 154 pela remissão Que ela faz o $\$ 4^{\circ}$ do artigo 195, ambos da Constituição Federal, não há Que se pretender Que seja ela inconstitucional por ter base de cálculo própria de impostos discriminados na Carta Magna ou igual à do PIS/PASEP (Que, por força da destinaçäo previdenciária Que the deu o artigo 239 da Constituição, the atribut a natureza de contribuição social), nem por não atender ela eventualmente à técnica da näocumulatividade. Ademais, no tocante ao PIS/PASEP, é a própria Constituição Federal Que admite que o faturamento do empregador seja base de cálculo para essa contribuição social e outra, como, no caso, é a COFINS. De efeito, se o PIS/PASEP, Que foi caracterizado, pelo artigo 239 da Constituiçăo, como contribuição social por the haver dado esse dispositivo constitucional permanente destinação previdenciária, houvesse 
Apesar de reconhecer a constitucionalidade da COFINS, a revogação ou não da isenção não fol objeto principal do julgamento, mas fez parte do voto de alguns ministros ${ }^{146}$. logo, não integra o mérito da ADC n. 1-1/DF, constituindo apenas um obter dictum ${ }^{147}$ (tipo "de passagem", referencialmente). Por outro lado, dá uma idéia da posição do STF, caso venha a se manifestar especificamente sobre a matéria.

Assim, a conseqüência do obter dictum, formado pelo STF relativamente à Lei Complementar n. 70/91 ter caráter material de lei ordinária e, formalmente, de lei complementar, é a possibilidade de ela ser modificada, em Qualeuer um dos seus pontos, por lei ordinária, ou até mesmo medida provisória. Seguindo esta premissa, a jurisprudência dos Tribunais Regionais Federais (TRF) ${ }^{148}$ pauta-se por tais alterações. ${ }^{149}$ Ex.: TRF $4^{a}$ Região, Apelação Cível n. 98.04.01866-7.

$\mathrm{Na}$ ADC n. I-1/DF, conforme voto do Ministro Moreira Alves (p. [23/124), a Lei Complementar n. 70/91 tem apenas o status formal de lei complementar, o Que não lhe dá a natureza de contribuição social nova, a ser aplicado o $\$^{\circ}$, do art. 195, da CF/88. Por isso, é materialmente lei ordinária, fora do campo da reserva à lei complementar. Esse já era o entendimento da Corte, ainda, sob o pálio da emenda n. I à Constituição Federal de 1969. a Qual a Constituição Federal de 1988 não se afastou. ${ }^{150}$

exaurido a possibłlidade de instituiçăo, por lei, de outra contribuiçãa social incidente sobre o faturamento dos empregadores, essa base de cálculo, por já ter sido utilizada, năo estaria referida no inciso l do artigo 195 Que é o dispositivo da Constituiçã́o Que disciplina, genericamente, as contribuiçôes socials, e que permite que, nos termos da lei (e, portanto, de lei ordinária, seja a seguridade social financiada por contribuição social incidente sobre o faturamento dos empregadores," ÁVILA, René Bergmann. PORTO, Éderson Garin. Cofins. Porto Alegre: Livraria do Advogado, 2005, p. 22-23.

${ }^{145}$ ÁVILA, René Bergmann. PORTO, Éderson Garin. Cofins. Porto Alegre: Livraria do Advogado, 2005, p. 19.

${ }^{146}$ Trecho do volo do Ministro Sydney Sanches, Quando do julgamento da ADC n. 1-1/DF: 'Sr. Presidente, como salientou o eminente Relator, a contribuição questionada foi instizuída por lei complementar, Quando poderia ter sido por lei ordinánia. Na verdade, a lei formalmente é complementar mas substancialmente ordinária.' ÁVILA, René Bergmann. PORTO, Éderson Garin. Cofins, Porto Alegre: Livraria do Advogado, 2005, p. 26.

${ }^{147}$ ÁVILA, René Bergmann. PORTO, Éderson Garin. Cofins. Porto Alegre: Livaria do Advogado, 2005, p. 78-79.

${ }^{1+}$ EX:: "MANDADO DE SEGURANÇA - CONSTITUCIONAL - TRIBUTÁRIO - SOCIEDADE CIVIL DE PRESTAÇÃO DE SERVIÇOS PROFISSIONAIS - COFINS - ISENÇÄO - ART. 6०, II, LC 70/9! REVOGAÇÃO - ART. 56, LEI N. 9.430/96 - LEGITIMIDADE - AUSÊNCIA DE HIERARQUIA ENTRE LE COMPLEMENTAR E ORDINÁRIA - PRECEDENTES - STF -. (TFR $3^{3}$ R. - AMS 190460 (1999.03.99.045529-9) - SP $-4^{a}$ T. - Rel. Desa. Fed. Salette Nascimento - DIU 11.04.2003 - p. $362)^{\prime}$; e, 'TRIBUTÁRIO - COFINS -- SOCIEDADES CIVIS PRESTADORAS DE SERVIÇOS PROFISSIONAIS REGULAMENTADOS EM LEI - ISENÇÃO PREVISTA NA LEI COMPIEMENTAR N. 70/91 - REVOGAÇÃO PELA LEI ORDINÁRJA - POSSIBILIDADE - AUSÊNCLA DE RESSALVAS NO ART. 56 DA LEI N. 9.430/96 - . (TRF 5 R. - AGTR 47368 - (2003.05.00.00070I - 0) - CE - $4^{\text {a }}$ T. - Rel. p/ o Ac. Des. Fed. Luiz Alberto Gurgel - DOU 17.06.2003 - p. 488).' ÁVILA, René Bergmann. PORTO, Éderson Garin. Colins. Porto Alegre: Livraria do Advogado, 2005, p. 27.

149 ÁVILA, René Bergmann. PORTO, Éderson Garin. Colns. Porto Alegre: Livraria do Advogado, 2005, p. 71.

${ }^{150}$.RENTZSCH, Cristiane Pederzolli. Lei complementar em matéria tributária. a possibilidade de revogação por lei ordinária. In: REVISTA DA FACULDADE DE DIREITO DA UNIVERSIDADE FEDERAL DO RIO GRANDE DO SUL. Porto Alegre: UFRGS, v. 21, p. 119, mar. 2002, semestral. Continuação de: Revista da Faculdade de Porto Alegre, 1949-1974. 
Apesar do entendimento do STF, o ST] vem se posicionando em sentido contrário, com base na hỉerarquia constitucional das leis, ou seja, a preponderância da lei complementar sobre a lei ordinária. ${ }^{15} \mathrm{O}$ caso concreto, reiteradamente discutido pela Corte, refere-se à revogação pela Lei $9.430 / 96$ da isenção da COFINS para as sociedades civis de prestação de serviços de profissão legalmente regulamentada (art. $1^{\circ}$. Decreto-Lei n. 2.397/87).

A tanto Que editou uma súmula sobre a matéria, a de número 276: "As sociedades civis de prestação de serviços profissionais são isentas da cofins, irrelevante o regime tributário adotado. 152

Porém, René Bergmann Ávila e Édcrson Garin Porto contestam o verbete sumular:

A edição da Súmula, contudo, gerou muita confusão, em especial porque, antes da sua edição ${ }^{153}$, outra discussão paralela foi levada ao STJ. Ocorre Que grande parcela dos operadores do direito entederam que a Súmula abrangia também definição do ST) sobre a validade da revogação da isenção (objeto do item 7.3.3 desta obra). A leitura atenta dos acórdãos que geraram a Súmula torna claro Que não é o caso: a súmula é restrita à análise dos requisitos da isenção desde a sua edição até a sua revogação, mas não a apreciação da validade ou invalidade da revogação propriamente dita. ${ }^{154}$

A Súmula 276 foi editada diante da discussão gerada pela Receita Federal, Que contrariando a obviedade do dispositivo legal, Que abrangia toda e Qualouer sociedade civil de profissão regulamentada, editou o Parecer Normativo n. 3/94, da Coordenadoria-Geral do Sistema de Tributação, e a Instrução Normativa DRF n. 2 1/92, passando a exigir recuisito não previsto na lei para o gozo da isenção, ou seja, a opção pela tributação na forma prevista no Decreto-Lei n. 2.397/87 $7^{155}$. Assim, as sociedades Que adotassem a tributação com base no lucro presumido ou lucro real do imposto de renda deveriam pagar a contribuição.

153 RENTZSCH, Cristiane Pederzolli. Lei complementar en matéria tributáriz. a possibilidade de revogação por lei ordinária. In: REVISTA DA FACULDADE DE DIREITO DA UNIVERSIDADE FEDERAL DO RIO GRANDE DO SUL. Porto Alegre: UFRGS, v. 21, p. 118, mar. 2002, semcstral. Continuaçäo de: Revista da Faculdade de Porto Alegrc, 1949-1974.

352 BRASil.. Superior Tribunal de lustiça. Súmula n. 276. Disponível em: «www.stj.gov.br/SCON/pesquisar.jsp» Acesso em: 28 mar. 2005, grifo nosso.

${ }^{153}$ A Súmula fot editada em 02.06.2003 e a isenção revogada em 27.12.1996, pela lei n. 9.430/96.

${ }^{154}$ ÁVILA, René Bergmann. PORTO, Éderson Garin. Cofins, Porto Alegre: Livraria do Advogado, 2005, p. 73.

thr "COFINS das sociedades civis de profissōes regulamentadas. Isenção. LC 70/91. ART. $6^{\circ}$, Il. DL 2.397/87, O art. 6०, II, da LC 70/9 l estabeleceu isençăo para as 'as sociedades civis de puc trata o art. $1^{\circ}$ do Decreto-Lei n. 2.397, de 21 de dezembro de 1987'. O art. $1^{\circ}$ do DL 2.397/1987, tratava do imposto de renda devido pelas 'sociedades civis de prestaçăo de serviços profissionais relativos ao exercício de profissão legalmente regulamentada, registradas no Registro Civil das Pessoas |urídicas e constituídas exclusivamente por pessoas físicas domicliadas no País'. O fato de tal isenção ter sido prevista por remissão ao Decreto-lei $2.397 / 87$ gerou discussões acerca de eventual condicionamento da isenção em função do regime de tributação adotado pela sociedade, eis que o referido DL 2.397/87 fazja referências nessa linha. O Parecer normativo Cosit n. 3/1994 pretendia condicionar a isenção da COFINS ao regime de apuraçäo do IRPI. Os tribunais, contudo, entederam que a remissão não tinha tal cxtensão. 
Apesar da aparente confusão em torno da súmula, os ministros da $1^{\text {a }}$ Seção do ST ${ }^{156}$, não aceitam a posição maj̣oritária da doutrina, muito menos do STF, e continuam a não aceitar a revogação da isenção. Assim, ante as decisões do STI, a União apresenta Reclamações ${ }^{157}$ no STF, alegando desrespeito ao julgamento da ADC n. 1/1/DF, e, invariavelmente, sai perdedora, porque, como já dito, a ADC n. 1-1/DF não decidiu sobre a revogação ou não da isenção. Logo, as reclamaçôes esbarram no aspecto processual.

Veja-se no STF, decisão monocrática do Ministro Carlos Velloso ${ }^{158}$ (Medida Cautelar na Reclamação n. 2.475/MG, julgada em 19.1 ( .2003, D|U 26. 11.2003 , p. 32), na qual a União buscava suspender julgamento, da $2^{\mathrm{a}}$ Turma do STI, Que no Agravo Regimental no Recurso Especial n. 429.610/MG, disse não estar revogada a isenção concedida pela Lei Complementar n. 70/91 às sociedades prestadoras de serviços, por lei ordinária.

Vẹam-se a súmula e os precedentes abaixo. Outra grande discussão diz respeito à validade da sua revogação da isençăo prevista na $L C$ pelo art. 56 da Lei 9.430/96. A Questão centrava-se na possibilidade ou não de lei ordinária ter revogado a isençáo, já estabelecida por lei complementar." PAUL.SEN, Leandro. Dircito tributário. constituição e código tributário à luz da doutrina e da jurisprudência. $6^{\mathrm{a}} \mathrm{ed}$. rev. atual. Porto Alegre: Livraria do Advogado: ESMAFE, 2004, p. 517, grifo do autor.

156 "EMBARGOS DE DJVERGÊNCIA - TRIBUTÁRIO - COFINS - SOCIEDADES CIVIS DE PRESTAÇÃO DE SERVIÇOS PROFISSIONAIS - ISENÇÄO RECONHECIDA PELA LEI COMPLEMENTAR N. 70/9I (ART. $6^{\circ}$, il) - REVOGAÇÃO PELA LEI ORDINÁRIA N. 9430/96 - INADMISSIBILIDADE - SÚMULA N. 276. Permitir-se que uma fonte formal de menor bitola possa revogar dispensa do pagamento da COFINS, conferida por lei complementar, resulta em desconsiderar a potencialidade hierarquicamente superior da lei complementar frente à lei ordinária. Nessa linha de raciocínło, o Professor Manoel Gonçalves Ferreira Filho, ancorado no magistério dos mestres Miguel Reale e Pontes de Miranda, elucida Que 'é princípio geral de direito que, ordinariamente, um ato só possa ser desfeito por outro que tenha obedecido à mesma forma' ( $\mathrm{c}$. Curso de Direito Consititucional, $18^{\mathrm{a}}$ ed., Saraiva, p. 184). As sociedades civis de prestação de serviços profissionais săo isentas da COFINS, irrelevante o regime tributário adotado' (Súmula n. 276/ST). Embargos de declaração acolhidos. (ST) - ERESP 354.012/SC - /a Seção - Rel. Min. Franciull Netto - j. 10.12.2003 - DJU 15.03.2004, p. 147)". ÁVILA, René Bergmann. PORTO, Éderson Garin. Cofins. Porto Alegre: Livraria do Advogado, 2005, p. 80-81; "TRIBUTÁRIO - COFINS - ISENÇAO - SOCIEDADE LIVRE: LC N. 70/91 - REVOGAÇÃO DA ISENÇÃO PELA LEI N. 9.430, DE 27/12/96. 1. Estabelecida a isenção da COFINS em lei complementar, não é lícita a supressão de favor fiscal por lei ordinária. Recurso especial provido." BRASiL. Superior Tribunal de Justiça. Recurso Especial n.

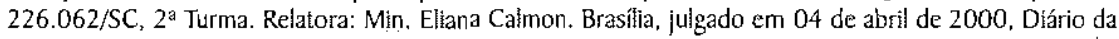
lustiça de 12 de junho de 2000. Disponivel em: www.stł.gov.br/websti/Processo/stimagem> Acesso en: 24 fev. 2005.

is7 Veja-se trecho do despacho em Reclamaçăo proposta pela Uniăo perante o STF, ante decisão da la Turma do STI, Que no julgamento do AG n. 490.277 desproveu agravo regimental, confirmando a isenção da COFINS para as sociedades civis prestadoras de serviços (STF, Reclamação n. 2.517/RI. Rel. Min. loaQuím Barbosa, fulgada em 18.12.2003, DIU 25.02.2004, p. 15): "A Fazenda Nacional funda o cabimento da reclamaçäo no julgamento da ADC I e no seu conseQüente efcito vinculante. Cita, para respaldar a sua tese, trecho do voto do Ministro Moreira Alves em Que se diz expressamente Que a Lei Complementar 70/91 possui natureza de lei ordinária. Isso permitiria, conforme ressalta, a revogação da lel complementar por lé ordinária - o Quie ocorreu, de fato, com a edição da Lei 9.430/96, cujo art. 56 revogou a isençăo da COFinS para as sociedades civis de prestação de serviços profissionais, concedida originariamente pelo art. $6^{\circ}$, II, da Lei Complementar 70/91. No caso em apreço, o ST] teria julgado o Agravo Regimental sob o pressuposto de que lei complementar somente pode ser revogada por outra lei complementar. Isso levaria à conclusão de Que o art. 56 da Lei ordinária 9.430/96 nâo poderia ter revogado a norma de isenção do art. $6^{\circ}$, Il, da Lei 
As decisões proferidas nas Reclamações, contudo, não adentraram no mérito da Questão - atendo-se apenas ao aspecto processual - como o fez o Ministro do STF Marco Aurélio, na Reclamação n. 2.61 3/RS, decisão de 24.05.2004, dizendo, em essência, Que, o problema naeuela Reclamação é assegurar a competência do STF para o julgamento da matéria decidida pelo STI, em desfavor da Uniáo, ou seja, a euestão da vigência dos arts. $6^{\circ}$. II, LC 70/91, e art. 56, Lei 9.430/96, frente à Constituição Federal de 1988, e não de simples revogação. $O$ ministro concedeu liminar na Reclamação, suspendendo os efeitos do julgamento do ST] até o julgamento final, restabelecendo, portanto, acórdão do TRF da $4^{\mathrm{a}}$ Região. Diz-se, por isso, ser a única Reclamação a adentrar no mérito da Questão. ${ }^{159}$

A posição do STF euanto a não exigência da lei complementar para a regulamentação da COFINS, o Que dá ensejo a sua alteração por lei ordinária, se coaduna frente as decisões, do próprio tribunal, em assuntos gerais sobre este jaez - competência material de leis e não hierarQuia entre lei complementar e lei ordinária - .

As Reclamações que constantemente chegam ao egrégio STF têm por fundamento Questão processual, Qual seja, Querem manter a autoridade da decisão do tribunal na ADC $n$. 1-1/DF, Quando, na verdade, esta não se manifestou materialmente em relação à revogaç̧ão da isenção da COFINS, a Qual constou apenas como obter dictum.

A revogação da isenção da COFINS para as sociedades civis, por lei ordinária, com a devida vênia das decisões do STI, desafiaria recurso extraordinário, pois diz respeito à obediência ou não das legislações infralegais ao Quanto prescreve a Constituição Federal de [988 e, por outro lado, estaria o ST] usurpando da sua competência, pois não pode tratar de assunto constitucional, como reiteradamente o faz, em sede de Recurso Especial.

Complementar 70/9I. Portanto, ainda segundo o reclamante, estaria o STI desconsiderando o efeito vinculante da $\mathrm{ADC}$ I, onde se teria decidido Que a Lei Complementar 70/9 I não é uma lei materialmente complementar, mas sim ordinária, podendo ser modificada por lei ordinária posterior. Por fim, pede a concessão de medida liminar para cassar a decisão reclamada. Feito esse breve relatório, passo a decidir. Pretende a reclamante conferir efeito vinculante a trecho do voto do Ministro Moreira Alves na ADC I. É bem verdade que, no caso, o voto do Ministro Moreira Alves sagrou-se vencedor. Todavia, é certo que o efeito vinculante das decisōes em Açóes Diretas de Constitucionalidade não abrange os chamados obiter dictz, proferidos em votos específicos. No caso da ADC 1, a afirmação do Ministro Moreira Alves de que a Lei Complementar 70/9I possui natureza de lei ordinária é um típico obiter dictum. Isso porque, da análise do acórdão da $\mathrm{ADC}$ I, não se percebe a afirmação citada como fundamento determinante da decisão - não alcançando, assim, o efeito vinculante. De fato, tudo leva a crer Que o afirmado pelo Ministro Moreira Alves constitui-se um verdadeiro obiter dictum. Tanto que o Ministro Carlos velloso foi expresso em despacho da Rd 2475: 'O efeito vinculante é da decisão proferida na açăo declaratória de constitucionalidade. A decisáo proferida na ADC I/DF, rełatada pelo Ministro Moreira Alves, limitou-se a 'conhecer em parte da ação, e, nessa parte, julgá-la procedente, para declarar, com os efeitos vinculantes previstos no $\$ 2^{\circ}$ do artigo 102 da Constítuição Federal, na redação da Emenda Constitucional n. $3 / 93$, a constitucionalidade dos artigos $1^{\circ}, 2^{\circ}$ e 10, bem como da expressão A contribuição social sobre o faturamento de Que trata esta lei complementar năo extingue as atuais fontes de custelo da Seguridade Social', contida no artigo $9^{\circ}$, e também da expressão 'Esta lei complementar entra em vigor na data de sua publicação, produzindo efeitos a partir do primeiro dia do mês seguinte aos noventa dias posteriores, àquela publicação, ... constante do artigo 13 , todos da lei Complementar n. 70, de 30.12.1991' (RT] 156/722). A decisão, está-se a ver, não assentou ser a Lei 


\section{CONCLUSÃo}

Inicialmente, sintetizou-se alguns aspectos sobre o processo legislativo brasileiro, mais especificamente sobre a lei, fonte formal por excelência do direito positivo nacional. Constatou-se que a Constituição Federal de 1988 é o ponto de partida de todo o processo legislativo, de onde provém a validade das demais fontes do direito vigente.

No aspecto das fontes legislativas, mereceram destaque a lei ordinária e a lei complementar, concluindo-se, portanto, Que as suas principais características são o Quórum de votação e campo de atuação, ambos com previsão na Constituição Federal de 1988. Nesta seara, a lei ordinária requer Quórum simples para aprovação, ou seja, votos favoráveis de metade mais um, ou primeiro número inteiro após a metade, dos integrantes da sessão legislativa, mas desde Que presentes a maioria Qualificada ou absoluta dos integrantes da respectiva Casa. Quanto ao campo de atuação, destaque-se o fato de Que, Quando a Constituição Federal de 1988 refere que tal assunto será tratado por lei, diz-se Que esta lei é a lei ordinária.

Em relação à lei complementar, esta para ser aprovada requer quórum qualificado, ou seja, votos de metade mais um, ou primeiro número inteiro após a metade, dos componentes da Casa Legislativa. No aspecto material, a Constituição Federal de 1988 é expressa ao requerer a lei complementar para tratar de determinada matéria, e assim também o faz para os casos em Que lei complementar tratará de aspectos gerais de certo assunto.

A partir das diferenças formais e materiais entre lei complementar e lei ordinária, chegou-se até o tema da suposta hierarquia entre as duas espécies normativas, o qual tem

Complementar 70/9: lei complementar simplesmente formal. É verdade Que, no voto do Ministro Relator isso foi dito (RT) 156/745). Trata-se, entretanto, de um obiter dictum. Também no meu voto expressei obiter dictum igual (RT) 156/752). Assin, pelo menos ao primeiro exame, não vejo configurado o fumus boni juris que autorizaria o deferimento da liminar'. Outro motivo impede o seguimento da presente Reclamaçăo. Se é verdade Que lei ordinária alterou o disposto na lei complementar no Que tange à isenção da COFINS, também é verdade que decisão deste Tribunal na $\mathrm{ADC} I$ não julgou a alteraçäo da lei complementar. mas a sua constitucionalidade anies da alteração. Ou seja, ainda que o afiłmado pelo Minịstro Moreira Alves representasse a voz da maioria - e não um obiter dictum -., a violação à autoridade do julgamento desta Corte seria, Quando muito, indireta, pois não foi objeto de juigamento peło Tribunal a alteração da lei complementar por lei ordinária posterior e nem se disse que isso deveria ter sido feito. Diante do exposto, e com base no art. 21, $\S^{\circ}$ do RISTE, nego seguimento à Reclamaçăo." ÁVILA, René Bergmann. PORTO, Éderson Garin. Cofins. Porto Alegre: Livraria do Advogado, 2005, p. 76-78.

${ }^{158}$ Conf̂ra-se parte do voto do ministro acima, por René Bergmann Ávila e Éderson Garin Porto: "A decisão, está-se a ver, não assentou ser a Lel Complementar $70 / 91$ lei complementar simplesmente formal. É verdade que, no voto do Ministro Relator isso foi dito (RT) 156/745). Trata-se, entretanto, de um obiter dictum. Também no meu voto expressei obiter dictum igual (RTI 156/752). Assim, pelo menos ao primeiro exame, não vejo configurado o fumus boni juris que autorizaria o deferimento da liminar. Do exposto indefiro a liminar." ÁVILA, René Bergmann. PORTO, Éderson Garin. Cofins. Porto Alegre: Livraria do Advogado, 2005, p. $78-79$.

is ÁVILA, René Bergmann. PORTO, Éderson Garin. Cofins. Porto Alegre: Livraria do Advogado, 2005, p. 79-80. 
indole eminentemente constitucional. Concluirse que não há hierarquia entre lei complementar e lei ordinária, no Que se refere ao rol do art. 59, da Constituição Federal de 1988. Contudo, o mesmo não se aplica Quando a lei complementar serve de validade para a edição da lei ordinária, ou seja, fundamenta esta, havendo, neste caso, hierarQuia.

Caso lei complementar trate de matéria para a Qual a Constituição Federal de 1988 nạ̃o requer lei de tal nível, será ela materialmente ordinária e formalmente complementar, vigorando como lei ordinária, mas o contrário não é verdadeiro. Lei ordinária Que invadir o cạmpo reservado à lei complementar será inconstitucional.

No aspecto da reserva legislativa surge a COFINS, contribuição para a seguridade social, criada com base no artigo 195. I, da Constituição Federal de 1988, e instituída por lei complementar - Lei Complementar n. 70/91 -. Problema surgiu com a edição da Lei Ordinária n. 9.430/96, a Qual, no art. 56, revogou a isenção da COFINS, concedida pela lei complementar, às sociedades civis de profissionais liberais. De bom alvitre frisar Que o problema não era sobre a isenção propriamente dita, mas sobre a competência legislativa.

Muito se discutiu se a revogação da isenção envolveria problema de hierareuia de leis, logo, poderia uma lei ordinária revogar assunto disciplinado originariamente por lei complementar. Conseoüentemente, adentraram no judiciário muitas ações Questionando a validade da revogação por lei ordinária da isenção concedida por lei complementar. Tenha-se em mente Que a COFINS - art. 195, I, CF/88 - não necessitava de lei complementar para ser instituída, e se assim o foi, aquela vigora como lei ordinária, podendo por esta espécie normativa ser modificada. Esta é a posição da doutrina e do Supremo Tribunal Federal.

Sobre a revogaçãa ou não da isenção se pronunciaram as duas mais altas cortes do pạis, Superior Tribunal de Justiça e Supremo Tribunal Federal. Contrariando a doutrina e a posição do Supremo Tribunal Federal, o Superior Tribunal de Justiça, no caso da COFINS, reconhece a hierareuia da lei complementar frente à lei ordinária estivesse ou não a matéria reservada àQuela na Constituição, diante do seu processo legislativo mais complexo - Quórum -. Salvo melhor juízo, as decisões do Superior Tribunal de Justiça são equivocadas.

Salta à baila, então, Que o Supremo Tribunal Federal, na Ação Direta de Constitucionalidade $\mathrm{n} .1-1 / \mathrm{DF}$, apenas reconheceu a constitucionalidade da COFINS, mas em passagens dos votos dos ministros - obiter dictum - constou Que a lei ordinária poderia revogar a isenção concedida pela lei complementar. A União Federal, então, através da Ação de Reclamaçâo, busca reverter as decisões do Superior Tribunal de Justiça desfavoráveis à revogação da isenção. Invariavelmente, as Reclamaçôes têm por fundamento o desrespeito à Ação Direta de Constitucionalidade n. 1 - l/DF, mas como esta não se manifestou no mérito sọbre a revogação da isenção, o Supremo Tribunal Federal, acertadamente, alega Que a Questão processual de desrespeito à sua decisão é inexistente porque não há decisão definitiva sobre a matéria, e não adentra no mérito.

Contudo, o Ministro do Supremo Tribunal Federal, Marco Aurélio, na Reclamação n. 2.6I 3/RS, em despacho de concessão de liminar para suspender os efeitos da decisão do 
Superior Tribunal de lustiça, foi o único a se pronunciar de maneira mais específica sobre o assunto, dizendo Que o problema, na verdade, não é de revogação ou não da isenção, mas de validade da Lei Complementar n. 70/91, art. 6 , II, e da Lei Ordinária n. 9.430/96, art. 56, Frente à Constituição Federal de 1988. Assim sendo, a matéria desafiaria Recurso Extraordinário e não Reclamação.

Ante os precedentes do Supremo Tribunal Federal sobre a falta de hierarouia entre lei complementar e lei ordinária em outros assuntos, sob o fundamento de haver, na verdade, uma reserva de competência legislativa pela Constituiçẫo Federal de 1988 à lei complementar, conciui-se que esta sofre uma Queda de status, se trata de matéria da alçada da lei ordinária, a cual tem processo legislativo mais simples. E, levando-se em consideração, ainda, a desnecessidade de lei complementar para a instituição da COFINS, somada aos obter dictum na Ação Direta de Constitucionalidade n. 1-1/DF, do Supremo Tribunal Federal, entende-se deva ser reconhecida a revogação da isenção para as sociedades civis de profissionais liberais, a partir da Lei $n$. 9.430/96, art. 56 .

\section{REFERÊNCIAS BIBLIOGRÁFICAS}

ÁvILA, Humberto. Sistema constitucional tributário: de acołdo com a emenda constitucional n. 42, de 19.12.03. São Paulo: Saraiva, 2004. 2005.

ÁVILA, René Bergmann. PORTO, Éderson Garin. Coffns. Porto Alegre: Livraria do Advogado,

BASTOS, Celso Ribeiro. Curso de direito constitucional. 2 [ a ed. atual. São Paulo: Saraiva; 2000.

BASTOS, Celso Ribeiro. Curso de direito financeiro e de direito tributário. $5^{2}$ ed. atual. São Paulo: Saraiva, 1997.

BORGES, José Souto Maior. Lei complementar tributária. São Paulo: RT, 1975.

BRASIL. Constituição (1988). In: CONSTITUIÇÃO DA REPÚBLICA FEDERATIVA DO BRASIL: promulgada em 05 de outubro de 1988. Antônio Luiz de Toledo Pinto et. al. (col.). $33^{\mathrm{a}} \mathrm{ed}$. atual. e ampl. São Paưlo: Saraiva, 2004. (Coleção Saraiva de Legislação)

BRASIL. Lei Complementar n. 70, de 30 de dezembro de 199!. Institui contribuição para financiamento da Seguridade Social, eleva a aliquota da contribuição social sobre o lucro das instituições financeiras, e dá outras providências. Diário Oficial da União, Brasília, 31 de dezentbro de 1991. Disponivel em: ‘www.senado.gov.br/sf/legisłação/legislà. Acesso em: 28 mar. 2005.

BRASIL. Lei n. 9.430, de 27 de dezembro de 1996. Dispõe sobre a legislação tributária federal, as contribuiçôes para a seguridade social, o processo administrativo de consulta e dá outras providências. Diário Oficial da Uniáo, Brasília, 30 de dezembro de 1996. Disponivel em: 〈www.senado.gov.br/sf/legislação/legisla. Acesso em: 28 mar. 2005. 
BRASIL. Superior Tribunal de Justiça. Recurso Especial n. 226.062/SC, $2^{\text {a }}$ Turma. Relatora: Min. Eliana Calmon. Brasília, julgado em 04 de abril de 2000. Diário da lustiça de 12 de junho de 2000. Disponivel em: 〈www.stj.gov.br/webstij/Processo/sțimagem>Acesso em: 24 fev. 2005.

BRASıl. Superior Tribunal de Justiça. Súmula n. 276. Disponível em: <www.stj.gov.br/SCON/ pesquisar.jsp> Acesso em: 28 mar. 2005.

BRASIL. Supremo Tribunal Federal. Recurso Extraordinário n. 407.190/RS. Pleno. Relator: Min. Marco Aurélio. Brastifia, 27 de outubro de 2004. In: Informativo 367, STF. Disponível em: «www.stf.gov.br/noticias/informativos/anteriores/info367.asp》. Acesso em: 28 mar. 2005. 1999.

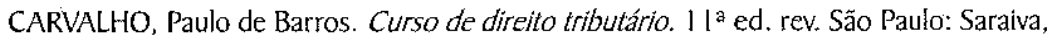

CHIMENTI, Ricardo Cunha. Direito tributário. $5^{\text {a }}$ ed. São Paulo: Saraiva, 2002, v. 16. (Coleção Sinopses Jurídicas)

COELHO, Sacha Calmon Navarro. Comentários à Constituição de 1988: sistema tributário. $7^{\mathrm{a}}$ ed, Rio de јапеiro: Forcnse, 1998.

DENARI, Zelmo. Curso de direito tributário. $6^{\mathrm{a}}$ ed. Rio de laneiro: Forense, 1998.

DIFINI, Luiz Felipe Silveira. Manual de direito tributário. São Paulo: Saraiva, 2003.

FERREIRA FILHO, Manoel Gonçaives. Curso de direito constitucional. $30^{\mathrm{a}}$ ed. rev. e atual. São Paulo: Saraiva, 2003.

FERREIRA FILHO, Manoel Gonçalves. Do processo legislativo. $3^{2}$ ed. atual. São Paulo: Saraiva, 1995.

MACHADO, Hugo de Brito. Curso de direito tributário. $25^{\circ}$ ed. rev., atual. e ampl. Säo Paulo: Malheiros, 2004.

MORAES. Alexandre de. Curso de direito constitucional. 12a ed. São Paulo: Atlas, 2002.

PAULSEN, Leandro. Direito tributário: constituição e código tributário à luz da doutrina e da jurisprudência. $6^{\text {a }}$ ed. rev. atua!. Porto Alegre: Livraria do Advogado: ESMAFE, 2004.

RENTZSCH, Cristiane Pederzolli. Lei complementar em matéria tributária. a possibilidade de revogação por lei ordinária. In: REVISTA DA FACULDADE DE DIREITO DA UNIVERSIDADE FEDERAL DO RIO GRANDE DO SUL. Porto Alegre: UFRGS, v. 21, p. 113-121, mar. 2002, semestral. Continuação de: Revista da Faculdade de Porto Alegre, 1949-1974.

ROSA IÚNIOR, Luiz Emygdio F da. Manual de direito financeiro e direito tributário. 1 la $^{\text {a }} \mathrm{ed}$. atual. e ampl. Rjo de Janeiro: Renovar, 1997.

SILVA, José Afonso da. Curso de direito constitucional positivo. $23^{\mathrm{a}}$ ed. rev. e atual. São Paulo: Malheiros, 2004. 